\title{
Modelling of organic aerosols over Europe (2002-2007) using a volatility basis set (VBS) framework: application of different assumptions regarding the formation of secondary organic aerosol
}

\author{
R. Bergström ${ }^{1,2}$, H. A. C. Denier van der Gon ${ }^{3}$, A. S. H. Prévôt ${ }^{4}$, K. E. Yttri ${ }^{5}$, and D. Simpson ${ }^{6,7}$ \\ ${ }^{1}$ Department of Chemistry and Molecular Biology, University of Gothenburg, 41296 Gothenburg, Sweden \\ ${ }^{2}$ Swedish Meteorological and Hydrological Institute, 60176 Norrköping, Sweden \\ ${ }^{3}$ TNO Netherlands Organisation for Applied Scientific Research, Utrecht, The Netherlands \\ ${ }^{4}$ Laboratory of Atmospheric Chemistry, Paul Scherrer Institut, Villigen, Switzerland \\ ${ }^{5}$ Norwegian Institute for Air Research, Kjeller, Norway \\ ${ }^{6}$ EMEP MSC-W, Norwegian Meteorological Institute, Oslo, Norway \\ ${ }^{7}$ Dept. Earth \& Space Sciences, Chalmers Univ. Technology, Gothenburg, Sweden
}

Correspondence to: D. Simpson (david.simpson@met.no)

Received: 3 January 2012 - Published in Atmos. Chem. Phys. Discuss.: 20 February 2012

Revised: 20 August 2012 - Accepted: 6 September 2012 - Published: 21 September 2012

\begin{abstract}
A new organic aerosol module has been implemented into the EMEP chemical transport model. Four different volatility basis set (VBS) schemes have been tested in long-term simulations for Europe, covering the six years 2002-2007. Different assumptions regarding partitioning of primary organic aerosol and aging of primary semi-volatile and intermediate volatility organic carbon (S/IVOC) species and secondary organic aerosol (SOA) have been explored. Model results are compared to filter measurements, aerosol mass spectrometry (AMS) data and source apportionment studies, as well as to other model studies. The present study indicates that many different sources contribute significantly to organic aerosol in Europe. Biogenic and anthropogenic SOA, residential wood combustion and vegetation fire emissions may all contribute more than $10 \%$ each over substantial parts of Europe. This study shows smaller contributions from biogenic SOA to organic aerosol in Europe than earlier work, but relatively greater anthropogenic SOA. Simple VBS based organic aerosol models can give reasonably good results for summer conditions but more observational studies are needed to constrain the VBS parameterisations and to help improve emission inventories. The volatility distribution of primary emissions is one important issue for further work. Emissions of volatile organic compounds from biogenic sources are also highly uncertain and need further vali-
\end{abstract}

dation. We can not reproduce winter levels of organic aerosol in Europe, and there are many indications that the present emission inventories substantially underestimate emissions from residential wood combustion in large parts of Europe.

\section{Introduction}

During the last $10-15$ yr carbonaceous aerosol has become one of the most intensively studied fields within the atmospheric sciences. This can be attributed to its postulated impacts on global climate (Novakov and Penner, 1993; Kanakidou et al., 2005), and on human health (McDonald et al., 2004). Particulate carbonaceous matter (PCM) contributes around 10-40\% (mean 30\%) to the total concentration of particulate matter (PM) with diameter less than $10 \mu \mathrm{m}$ $\left(\mathrm{PM}_{10}\right)$ at rural and natural background sites in Europe (Yttri et al., 2007; Putaud et al., 2004). PCM consists largely of organic matter (OM, of which typically $40-80 \%$ is OC: organic carbon (Turpin and Lim, 2001; El-Zanan et al., 2009), with the rest made up of associated oxygen, hydrogen, and other atoms) and so-called elemental or black carbon (EC or $\mathrm{BC})$. The sum of EC and $\mathrm{OC}$ is referred to as total carbon (TC). OM is a very important fraction of sub-micron particles $\left(\mathrm{PM}_{1}\right)$ as well. In a recent aerosol mass spectrometry

Published by Copernicus Publications on behalf of the European Geosciences Union. 
(AMS) study of non-refractory (NR) $\mathrm{PM}_{1}$ in Central Europe, Lanz et al. (2010) found that about $40-80 \%$ of the NR-PM 1 was made up of OM.

The EMEP EC/OC model has previously been presented by Simpson et al. (2007); two versions of a gas-particle scheme for secondary organic aerosol (SOA) were used, Kam-2 from Andersson-Sköld and Simpson (2001), and a modification, Kam-2X, which use alternative "effective" vapour pressures, for the semi-volatile organic aerosol compounds, to increase partitioning to the particulate phase. Model results were compared with measurements from the EMEP EC/OC campaign (Yttri et al., 2007) and the EU CARBOSOL project (Legrand and Puxbaum, 2007). Comparisons were also made of the different components of TC, e.g. anthropogenic and biogenic secondary organic aerosols (ASOA, BSOA) from emitted volatile organic compounds, against observation-based estimates of these compounds made by Gelencsér et al. (2007).

The study demonstrated that the Kam-2 and Kam-2X schemes were able to predict observed levels of OC in Northern Europe fairly well, but for southern Europe the model underestimated OC significantly. In wintertime, the underprediction was shown to be caused by problems with woodburning emissions (possibly local). In summer the problems were due to an under-prediction of the SOA components. The model results were very sensitive to assumptions concerning the vapour pressures of the model compounds.

As discussed in, e.g. Hallquist et al. (2009), the sources and formation mechanisms of SOA are still very uncertain, with many plausible pathways but still no reliable estimates of their relative importance. In such a situation one cannot expect a model to accurately reproduce measurements. Still, it is important to understand the extent to which models or parameterisations derived from smog-chambers can capture observed levels and variations in OC.

Donahue and co-workers introduced the use of a volatility basis set (VBS) to help models cope with the wide range of organic aerosol species and the oxidation of organics of different volatilities in the atmosphere (see, e.g. Donahue et al., 2006, 2009). This scheme is suitable for regional and global scale modelling of organic aerosol as it provides a convenient framework with the aerosol described by a physically plausible range of properties, and simple relationships governing partitioning and transformation of OA.

In this paper we explore the use of the VBS approach for modelling organic aerosol over Europe with the EMEP model (Simpson et al., 2007, 2012), and illustrate the sensitivity of the results to some key parameters. The model results are compared with PCM measurements of different types from a number of European campaigns from the years 2002-2007.

However, the large number of different components that contribute to PCM makes a simple comparison of modelled versus observed TC or OC potentially misleading. For example, OC from wood combustion often contributes substan- tially to observed TC levels, but emission inventories may often miss the relevant sources. Model-measurement discrepancies might easily be misinterpreted in terms of problems with, for example, the SOA components. In such situations additional components, such as levoglucosan, a well-known tracer for primary organic aerosol (POA) from wood burning, can provide valuable information on the reasons for model discrepancies. Indeed, levoglucosan comparisons could explain almost all of the wintertime discrepancies between modelled and observed data at two CARBOSOL sites, as shown in Simpson et al. (2007).

Thus, it is necessary to compare model results not only to measured OC, EC and TC but also to source apportionment (S-A) studies that give information about the relative contributions from different sources to PCM (e.g. wood-burning, BSOA, etc.). Here we compare model results to S-A studies which have been analysed with approximately the same methodology: the 2-yr CARBOSOL campaign (Gelencsér et al., 2007) at sites in central Europe, the SORGA (Yttri et al., 2011) campaign in and close to Oslo in southern Norway, and the Göte-2005 campaign (Szidat et al., 2009) in and close to Gothenburg in southern Sweden. All of these campaigns made use of radiocarbon $\left({ }^{14} \mathrm{C}\right)$ data as well as of compounds that could be used as tracers for wood-burning and primary biological aerosol particles.

A large number of new measurements has become available recently, e.g. through the EUCAARI (Kulmala et al., 2011) and other projects (e.g. Lanz et al., 2010; Aas et al., 2012). These data mainly consist of relatively short-term campaigns (typically 1 month), but with very high time resolution and multiple instruments. These will be analysed in a subsequent paper; the main focus of this paper is to provide an initial assessment of the different VBS schemes against long-term observations, and especially for sites where some source apportionment results are already available.

\section{The EMEP model}

The EMEP MSC-W (Meteorological Synthesizing CentreWest) model is a development of the 3-D chemical transport model of Berge and Jakobsen (1998), extended with photooxidant and inorganic aerosol chemistry (Andersson-Sköld and Simpson, 1999; Simpson et al., 2003, 2012), and, in this work, organic aerosol modules. Here, we use model version $\operatorname{rv} 4 \beta$, which is identical to the rv4 version documented in Simpson et al. (2012) except for some minor updates in emissions (see below).

The model domain used in this study covers all of Europe, and includes a large part of the North Atlantic and Arctic areas. A horizontal resolution of ca. $50 \times 50 \mathrm{~km}^{2}$ is used. The model includes 20 vertical layers, using terrain-following coordinates; the lowest layer has a thickness of about $90 \mathrm{~m}$. The EMEP model is mainly designed to study the largescale distribution of organic aerosol in Europe and we mostly 
compare to measurements at sites representative for regional background concentrations; however, we also include comparison with some urban background locations where we believe the local contributions to the organic aerosol are not too large.

The meteorological driver has changed recently. For the years up to 2005, we use PARLAM-PS - a dedicated version of the HIRLAM (HIgh Resolution Limited Area Model) numerical weather prediction model, with parallel architecture (Bjørge and Skålin, 1995; Benedictow, 2003). For 2006 and later years, meteorological fields are derived from the European Centre for Medium Range Weather Forecasting Integrated Forecasting System (ECMWF-IFS) model (http: //www.ecmwf.int/research/ifsdocs/). The performance of the EMEP model varies with the meteorological driver, but differences are modest for most pollutants. Tarrasón et al. (2008) discuss the differences in more detail.

The EMEP PCM model uses the same inorganic and gasphase organic chemistry scheme, and deposition routines, as the standard EMEP model (Simpson et al., 2012), with additional SOA forming reactions. The model uses essentially two modes for particles, fine and coarse aerosol, although assigned sizes for some coarse aerosol vary with compound. The parameterization of the wet deposition in the model is based on Berge and Jakobsen (1998) and includes in-cloud and sub-cloud scavenging of gases and particles. Further details, including scavenging ratios and collection efficiencies, are given in Simpson et al. (2012). Dry deposition of semivolatile organic vapours may be an important loss process for OA (Bessagnet et al., 2010). In this study we assume that the dry deposition velocities of the semi-volatile components in the gas phase are the same as for higher aldehydes, which entails very low deposition $\left(<0.1 \mathrm{~cm} \mathrm{~s}^{-1}\right)$ in winter, but between 0.1 to $0.4 \mathrm{~cm} \mathrm{~s}^{-1}$ in summer. (For comparison, the deposition velocities of fine particulate $\mathrm{OM}$ range from about $0.1 \mathrm{~cm} \mathrm{~s}^{-1}$ in winter to $0.2-0.3 \mathrm{~cm} \mathrm{~s}^{-1}$ in summer.)

Boundary concentrations of most long-lived model components are set using simple functions of latitude and month (see Simpson et al., 2012 for details). For ozone, more accurate boundary concentrations are needed and these are based on climatological ozone-sonde data-sets, modified monthly against clean air surface observations at Mace Head on the west coast of Ireland (Simpson et al., 2012).

We assume a background concentration of $1.0 \mu \mathrm{g} \mathrm{m}^{-3}$ of organic particles (with a ratio of organic mass to organic carbon, OM/OC, of 2.0, i.e., background $\mathrm{OC}=0.5 \mu \mathrm{g}(\mathrm{C}) \mathrm{m}^{-3}$ ) at the surface, decaying vertically with a scale height of $9 \mathrm{~km}$. As used in Simpson et al. (2007), this choice of $0.5 \mu \mathrm{g}(\mathrm{C}) \mathrm{m}^{-3}$ was loosely based upon measurements at Mace Head (Cavalli et al., 2004; Kleefeld et al., 2002), the Azores (Pio et al., 2007) and at other remote locations (Heintzenberg, 1989). This background OA is assumed to be nonvolatile and represents, in a very simplified way, the sources of OA that are not included in the model, e.g., OA from oceanic sources and primary biological material. The validity of this assumption is discussed in Sect. 5.4. All of the background $\mathrm{OA}$ is included in the fine aerosol mode in the model, that is, considered as part of the PM with diameter less than $2.5 \mu \mathrm{m}\left(\mathrm{PM}_{2.5}\right)$.

The PCM model uses the same basic gas/aerosol partitioning framework as in Simpson et al. (2007), but using the VBS approach rather than the earlier 2-parameter or gas/kinetics ("Kam-2(X)") schemes of Andersson-Sköld and Simpson (2001) or Simpson et al. (2007). The VBS approaches used in this paper will be described in Sect. 4. We assume that the semi-volatile OA only partitions to the $\mathrm{PM}_{2.5}$ fraction of the organic material, that is, not to coarse particles or the elemental carbon (EC).

Before going into detailed model evaluation for the organic aerosol, with its many complications and uncertainties, it is important to know that the model works well for other components. The EMEP model has been extensively compared with measurements of sulphate, nitrate, ozone, $\mathrm{NO}_{2}$ and other compounds (Fagerli and Aas, 2008; Jonson et al., 2006; Simpson et al., 2006a,b; Aas et al., 2012) (and in many annual EMEP reports, see www.emep.int). Nitrogen oxides are probably most akin to $\mathrm{OA}$, in that they have large fraction of ground-level sources, which are oxidised to both gaseous and particulate forms. Fagerli et al. (2011) showed that modelled mean $\mathrm{NO}_{2}$ levels were very well captured by the EMEP model for the year 2009 (3\% bias over all stations, maps of normalised mean bias showing values lower than $18 \%$ across most of Europe). Total nitrate in air $\left(\mathrm{HNO}_{3}+\mathrm{NO}_{3}^{-}\right)$was underpredicted by about $30 \%$ (ibid). These evaluations give some confidence to the underlying meteorology, and physical and chemical structure of the model.

\subsection{Emissions}

Two types of emissions are included in the model: anthropogenic and natural. Anthropogenic emissions are provided annually by all countries within EMEP, and gridded to the standard EMEP $50 \times 50 \mathrm{~km}^{2}$ emissions domain (http://www. emep.int/grid/). Non-methane volatile organic compounds (NMVOC) are speciated into 11 surrogate compounds, using emission-sector specific values as shown in Simpson et al. (2012). The temporal variation of the anthropogenic emissions is source dependent and varies with year, month and day of the week. In the model version used here, $\operatorname{rv} 4 \beta$, simple day-night factors are used (one factor for day-time and another for night), where day is defined as 07:00-18:00 local time. In version rv4 hourly factors were introduced, but tests have showed that this change has negligible impact on the results presented here. Further details of the temporal distribution of emissions are given in Simpson et al. (2012). 


\subsubsection{Biogenic VOC emissions}

Biogenic emissions of isoprene and monoterpenes are calculated in the model for every grid-cell, and at every model timestep, using near-surface air temperature and photosynthetically active radiation (Guenther et al., 1993; Simpson et al., 1999), together with maps of standardised emission factors.

As detailed in Simpson et al. (2012), the maps of standard emission factors have been extensively revised over the last year. The new procedures make use of updated emission rates together with maps of forest species from Köble and Seufert (2001). This work (also used by Karl et al., 2009 and Kesik et al., 2005) provided maps for 115 tree species in 30 European countries, based upon a compilation of data from the ICP-forest network (UN-ECE, 1998).

Sesquiterpene emissions are not included in the present model version, primarily because of major uncertainties regarding their emissions and the environmental factors controlling the emissions (Duhl et al., 2008).

\subsubsection{Vegetation fire emissions}

Emissions of gases and carbonaceous particles from vegetation fires (open-burning wildfires and agricultural fires) are taken from the Global Fire Emission Database (GFEDv2, van der Werf et al., 2006, Giglio et al., 2003, Tsyro et al., 2007). The database provides emissions with $1^{\circ} \times 1^{\circ}$ spatial resolution and 8-days temporal resolution for the years 20022007. The low time resolution of these emissions leads to a corresponding uncertainty in the model predictions in and around periods of heavy vegetation fires.

We assume an initial OM/OC ratio of 1.7 for organic aerosol emissions from vegetation fires (based on AMS measurements presented by Aiken et al., 2008). The OM/OC ratio increases as the aerosol ages by OH-reactions in the atmosphere (see Sect. 4).

Emissions of volatile organic compounds (VOC) from vegetation fires (and residential wood burning) are included in the model but in the present model versions the formation of SOA from these VOCs is not separated from SOA from anthropogenic fossil VOC emissions. This may lead to a slight overestimation of the fossil OC in the model, and corresponding underestimation of modern OC, but in Europe the VOC emissions from forest fires are usually minor in comparison with anthropogenic fossil VOC emissions and Bessagnet et al. (2008) have suggested that the SOA contribution from wildfires is small, even during a period of relatively intense fires in Europe. Cubison et al. (2011), summarising the results of a number of studies, also suggested that on average SOA formation from forest fires was relatively small, about $20 \%$ of POA, although with substantial variability.

\subsubsection{EC and OC emissions}

Carbonaceous aerosol emissions from anthropogenic sources are taken from the emission inventory by Denier van der Gon et al. (2009) (see also Visschedijk et al., 2009 for details), prepared as part of the EUCAARI project (Kulmala et al., 2011). To make a carbonaceous aerosol inventory there are essentially two options:

1. to use direct EC and OC emission factors per unit of activity (e.g. g EC emitted per kg coal burned in a particular type of stove) or,

2. to establish the fraction $\mathrm{EC}$ and $\mathrm{OC}$ for $\mathrm{PM}_{10}$ and $\mathrm{PM}_{2.5}$ emissions per unit of activity (e.g. $\mathrm{EC}=\mathrm{x} \%$ of $\mathrm{PM}_{2.5}$ emitted per $\mathrm{kg}$ coal burned in a particular type of stove).

The EUCAARI EC and OC inventory follows the latter option. The motivation was that size-fractionated EC and OC emission factors (carbonaceous mass per unit of activity) are available only for a limited number of sources and technologies, and can vary widely due to different measurement protocols and analytical techniques (e.g. Watson et al., 2005). Therefore, although in principle a direct calculation of activity $\times$ EC or OC emission factor would be preferable, this would give widely varying, inconsistent and incomplete results.

Option 2 tackles this problem by starting from a sizefractionated particulate matter $\left(\mathrm{PM}_{10} / \mathrm{PM}_{2.5} / \mathrm{PM}_{1}\right)$ emission inventory followed by deriving and applying representative size-differentiated EC and OC fractions to obtain the EC and OC emissions in the size classes, $<1 \mu \mathrm{m}, 1-2.5 \mu \mathrm{m}$ and 2.5$10 \mu \mathrm{m}$. The total EC and OC emission is then constrained by the amount of PM emitted. This limits uncertainty because extremes in the EC or OC emission factors measured can never generate more EC or OC than the total amount of PM in a particular size class.

The PM emission inventory needs to be consistent for all countries. It is based on previous PM inventories, especially the PM module of the IIASA GAINS model (Kupiainen and Klimont, 2004, 2007). Representative elemental and organic carbon (OC) fractions are selected from the literature and applied to ca. 200 individual GAINS PM source categories and separated in the three size classes.

Fuel wood is used extensively in Europe. Combustion of wood is a major source of EC and OC but reliable fuel wood statistics are difficult to obtain because fuel wood is often non-commercial and falls outside the economic administration. In this study the residential wood burning emissions from Visschedijk et al. (2009) are used. Visschedijk et al. updated and adjusted the residential wood use activity data per appliance type. This led to changes, compared to the GAINS activity data, to varying degrees for 17 countries in Europe. For the entire domain the estimated fuel wood use increased by $25 \%$, but this includes data from countries where no previous estimates were available. 


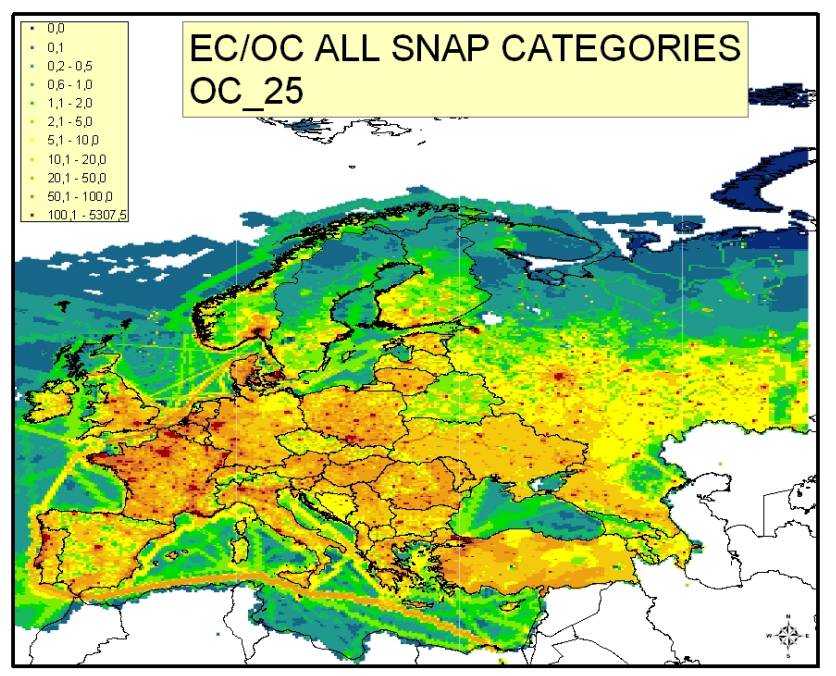

Fig. 1. Emission intensity pattern of $\mathrm{OC}$ in $\mathrm{PM}_{2.5}$ over Europe (low to high: blue, green, yellow, orange, red). Unit: tonnes gridcell ${ }^{-1} \mathrm{yr}^{-1}$.

Another important feature of the new inventory is its improved spatial resolution of $1 / 8^{\circ} \times 1 / 16^{\circ}$ lon-lat (or $\sim 7 \mathrm{~km} \times 7 \mathrm{~km}$ ) compared to previous inventories. The emissions are gridded using especially prepared distribution maps. Particular attention has been given to the spatial distribution of transport emission and emission due to residential combustion. An example of the emission distribution pattern for $\mathrm{OC}_{\mathrm{PM}_{2.5}}$ (organic carbon in particles with diameter $<2.5 \mu \mathrm{m}$ ) is presented in Fig. 1. The emissions are dominated by transport and residential combustion as can be seen by the highlighted urban centers, major road network and ship tracks.

Total carbonaceous aerosol emissions in $\mathrm{PM}_{2.5}$ are presented in Table 1. Total $\mathrm{PM}_{2.5}$ emissions in Europe amount to $\sim 3400$ ktonnes and about half of the total $\mathrm{PM}_{2.5}$ emissions in Europe are carbonaceous aerosol, highlighting the importance of this fraction. Elemental carbon emissions are dominated by road transport and residential combustion (each $\sim 30 \%$; Table 1) but for OC residential combustion is clearly the dominant source, responsible for almost $50 \%$ of the European emissions (Table 1).

Particle size distributions of EC and OC for mass show maxima in the range of 80 to $200 \mathrm{~nm}$, thus being highly relevant for long range atmospheric transport. In the present EMEP PCM model only two size classes are used for the EC and $\mathrm{OC}$ emissions, PM-fine (up to $2.5 \mu \mathrm{m}$ ) and PM-coarse $(2.5-10 \mu \mathrm{m})$, thus the $\mathrm{PM}_{1}$ and $\mathrm{PM}_{1-2.5}$ classes from the emission inventory are combined.

Emissions in the inventory are given in $\operatorname{ktonne}(\mathrm{C}) \mathrm{yr}^{-1}$. In the model this is converted to OM-emissions using the $\mathrm{OM} / \mathrm{OC}$ ratios 1.25 for fossil fuel emissions and 1.7 for wood burning emissions, based on data from laboratory and field measurements (Aiken et al., 2008).

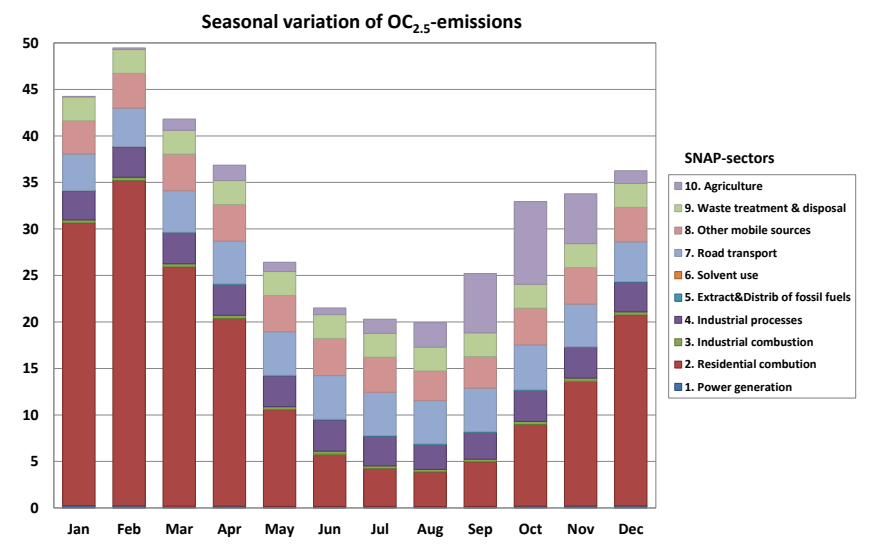

Fig. 2. Monthly variation of anthropogenic primary OC emissions $(<2.5 \mu \mathrm{m})$ in 17 European countries (EU15 + Norway and Switzerland), specified by source-sector. Unit: ktonnes(C) month ${ }^{-1}$.

There are strong seasonal variations in EC and OC emissions. These are estimated from annual emissions according to SNAP-sector ${ }^{1}$ and country (Simpson et al., 2012). As an example, Fig. 2 provides an estimate of the monthly variation of OC emissions in 17 European countries. The seasonal variation is largest for the residential heating sector, with very low emissions during the summer months and large winter emissions.

The emission inventory used in this work has only small contributions from cooking emissions. This may lead to an underestimation of organic aerosol, especially in urban areas. We discuss this in more detail in Sect. 6.

\section{Observations}

The main focus of this paper is to provide an initial assessment of the different VBS schemes against long-term observations, including sites for which some source apportionment data are available. Table 2 gives a list of the sites used, and Fig. S1 illustrates their location. Below we discuss briefly the origin of the data for these sites, and their representativeness.

The CARBOSOL 2002-2004 campaign provided two years of measured data, together with source apportionment for summer and winter seasons. These sites, data and the source apportionment have been described in detail in: Legrand and Puxbaum (2007); Pio et al. (2007); Gelencsér et al. (2007); Simpson et al. (2007). Measurements were made at six sites in a transect across southern-central Europe. Two of these sites, K-Puszta (Hungary) and Aveiro (Portugal) are very well suited for EMEP model evaluation

\footnotetext{
${ }^{1}$ SNAP = Selected Nomenclature for sources of Air Pollution, developed within the CORINAIR project, see EMEP/CORINAIR Emission Inventory Guidebook - 3rd edition, EEA, Technical report No 30/2002, available at www.eea.europa.eu/publications/ technical_report_2001_3
} 
Table 1. Estimated EC and OC emissions $(<2.5 \mu \mathrm{m})$ for UNECE Europe in 2005 by source sector $\left(\mathrm{ktonne}^{(\mathrm{C})} \mathrm{yr}^{-1}\right)$.

\begin{tabular}{lrrrr}
\hline & EC & OC \\
SNAP Description & $\mathrm{kt} \mathrm{yr}^{-1}$ & $\%$ & $\mathrm{kt} \mathrm{yr}^{-1}$ & $\%$ \\
\hline 1. Combustion in energy industries & 20 & 3 & 11 & 1 \\
2. Residential and non-industrial combustion & 186 & 30 & 395 & 47 \\
3. Combustion in manufacturing industry & 6 & 1 & 9 & 1 \\
4. Production processes & 36 & 6 & 81 & 10 \\
5. Extraction and distribution of fossil fuels & 4 & 1 & 1 & 0 \\
6. Solvent use & 0 & 0 & 0 & 0 \\
7. Road transport & 201 & 32 & 104 & 12 \\
8. Other mobile sources and machinery & 95 & 15 & 71 & 8 \\
9. Waste treatment and disposal & 37 & 6 & 63 & 7 \\
10. Agriculture & 36 & 6 & 112 & 13 \\
\hline Total excluding international shipping & 623 & 100 & 848 & 100 \\
\hline International shipping & 124 & & 84 & \\
\hline
\end{tabular}

since they are located in rural areas, and at low elevation. We have also made use of data from two of the elevated sites from the CARBOSOL campaign, Schauinsland (Germany) and Puy de Dome (France), since they are usually located within the planetary boundary layer in summertime, although not usually in winter time. We have excluded the remote Azores and the very high-altitude station Sonnblick since they are not representative of European boundary layer pollution levels.

Other long-term data-sets consist of the EMEP EC/OC campaign 2002-2003 (Yttri et al., 2007), and the EMEP PM intensive campaign 2006-2007 (Yttri et al., 2008; Aas et al., 2012). As noted in Yttri et al. (2007) most of these sites are established EMEP sites, which fulfil the criteria of regional background sites. Penicuik (Scotland) is also a regional background site, although not an EMEP site. Gent (Belgium) and San Pietro Capofiume (Italy) are both urban background sites. Some of the EMEP sites are also quite elevated; we will discuss the implications of this while discussing the results in Sect. 5.

For source apportionment data, we make use of three studies: CARBOSOL as discussed above, the SORGA campaign in and near Oslo in southern Norway (Yttri et al., 2011), and the Göte-2005 campaign in and near Gothenburg in southern Sweden (Szidat et al., 2009). All of these campaigns made use of radiocarbon $\left({ }^{14} \mathrm{C}\right)$ data as well as of compounds that could be used as tracers for wood-burning and primary biological aerosol particles. Further, these source apportionment studies were all conducted with different variants of the same methodology, using Latin-hypercube-sampling to allow for a wide range of uncertainties in the relations between tracers and their associated TC components. The Oslo and Gothenburg sites are urban, which raises some problems when comparing with results from the EMEP model; this will be addressed where appropriate in Sect. 5.
Aerosol mass spectrometry is becoming a very important technique for studying submicron particles $\left(\mathrm{PM}_{1}\right)$ at high time-resolution (e.g. Canagaratna et al., 2007). We plan a more extensive comparison with AMS data in a complementary study, here we compare model results to observations from one AMS-campaign, in Switzerland in June 2006 (Lanz et al., 2010), in order to give a first impression of model performance at higher time-resolution.

\section{VBS experiments}

The VBS approach was introduced by Donahue and coworkers (Donahue et al., 2006, 2009), as a practical approach to dealing with the complexity of organics in the atmosphere. The VBS consists of a group of lumped compounds with fixed saturation concentrations $\left(C^{*}, \mu \mathrm{g} \mathrm{m}^{-3}\right)$, comprising a number of bins separated by one order of magnitude each in $C^{*}$ at $298 \mathrm{~K}$. Different SOA-forming reactions can be mapped onto the same set of bins over the range of organic aerosol mass concentration typical of ambient conditions (0.1-100 $\mathrm{g} \mathrm{m}^{-3}$ ) while maintaining mass balance for more volatile co-products as well. Aging reactions can be added easily within the VBS if the kinetics and volatility distribution of the products can be measured or estimated.

A number of papers have illustrated the use of VBS-based models in North America (Robinson et al., 2007; Lane et al., 2008a,b; Shrivastava et al., 2008; Murphy and Pandis, 2009), Mexico City (e.g. Dzepina et al., 2009, Hodzic et al., 2010a, Tsimpidi et al., 2010, Li et al., 2011, Shrivastava et al., 2011), and very recently in Europe (Simpson et al., 2009; Fountoukis et al., 2011), and we build upon this work here.

In the EMEP models for particulate carbonaceous matter (EMEP-PCM) a small four-bin VBS is used for the SOA components (saturation concentrations in the range 1$1000 \mu \mathrm{g} \mathrm{m}^{-3}$ ) as in Lane et al. (2008b). A larger basis set, 
Table 2. Measurement sites and campaigns used in this study (see also Fig. S1).

\begin{tabular}{|c|c|c|c|c|c|c|}
\hline & Country & Latitude & Longitude & Alt. (m a.s.1.) & Measurements & Notes \\
\hline Schauinsland [DE03] & Germany & 47.91 & 7.91 & 1205 & $\mathrm{EC}, \mathrm{OC}, \mathrm{S}-\mathrm{A}^{\dagger}, \mathrm{PM}_{10}$ & (a), (g) \\
\hline Puy de Dome [FR30] & France & 45.77 & 2.95 & 1450 & $\mathrm{EC}, \mathrm{OC}, \mathrm{S}-\mathrm{A}, \mathrm{PM}_{10}$ & (a), (g) \\
\hline K-puszta [HU02] & Hungary & 46.97 & 19.58 & 125 & $\mathrm{EC}, \mathrm{OC}, \mathrm{S}-\mathrm{A}, \mathrm{PM}_{2.5}$ & (a) \\
\hline Aveiro [AVE] & Portugal & 40.58 & -8.64 & 47 & $\mathrm{EC}, \mathrm{OC}, \mathrm{S}-\mathrm{A}, \mathrm{PM}_{2.5}$ & (a) \\
\hline Virolahti [FI17] & Finland & 60.53 & 27.69 & 8 & $\mathrm{EC}, \mathrm{OC}, \mathrm{PM}_{10}$ & (b) \\
\hline Aspvreten [SE12] & Sweden & 58.80 & 17.38 & 20 & $\mathrm{EC}, \mathrm{OC}, \mathrm{PM}_{10}$ & (b) \\
\hline Birkenes [NO01] & Norway & 58.38 & 8.25 & 190 & $\mathrm{EC}, \mathrm{OC}, \mathrm{PM}_{10}, \mathrm{PM}_{2.5}(2006,2007)$ & (c), (d) \\
\hline Penicuik [GB46] & United Kingdom & 55.86 & -3.21 & 180 & $\mathrm{EC}, \mathrm{OC}, \mathrm{PM}_{10}$ & (b) \\
\hline Kollumerwaard [NL09] & the Netherlands & 53.33 & 6.28 & 0 & $\mathrm{EC}, \mathrm{OC}, \mathrm{PM}_{10}$ & (b) \\
\hline Mace Head [IE31] & Ireland & 53.33 & -9.90 & 25 & $\mathrm{EC}, \mathrm{OC}, \mathrm{PM}_{10}$ & (b) \\
\hline Langenbrügge [DE02] & Germany & 52.80 & 10.76 & 74 & $\mathrm{EC}, \mathrm{OC}, \mathrm{PM}_{10}$ & (b) \\
\hline Gent $[\mathrm{BE} 05]$ & Belgium & 51.05 & 3.72 & 0 & $\mathrm{EC}, \mathrm{OC}, \mathrm{PM}_{10}$ & (b) (h) \\
\hline Kosetice [CZ03] & Czech Republic & 49.58 & 15.08 & 534 & $\mathrm{EC}, \mathrm{OC}, \mathrm{PM}_{10}$ & (b), (c) \\
\hline Stara Lesna [SK04] & Slovakia & 49.15 & 20.28 & 808 & $\mathrm{EC}, \mathrm{OC}, \mathrm{PM}_{10}$ & (b) \\
\hline Illmitz [AT02] & Austria & 47.77 & 16.77 & 117 & $\mathrm{EC}, \mathrm{OC}, \mathrm{PM}_{10}, \mathrm{PM}_{2.5}(\mathrm{~S}, 2006)$ & (b), (c), (j 2006) \\
\hline Ispra [IT04] & Italy & 45.80 & 8.63 & 209 & $\mathrm{EC}, \mathrm{OC}, \mathrm{PM}_{10}(2002-2003), \mathrm{PM}_{2.5}(2006,2007)$ & (b), (c) \\
\hline San Pietro Capofiume [IT10] & Italy & 44.48 & 11.33 & 10 & $\mathrm{EC}, \mathrm{OC}, \mathrm{PM}_{10}$ & (b), (h) \\
\hline Braganca [PT01] & Portugal & 41.82 & -6.77 & 691 & $\mathrm{EC}, \mathrm{OC}, \mathrm{PM}_{10}$ & (b) \\
\hline Harwell [GB36] & United Kingdom & 51.57 & -1.32 & 137 & $\mathrm{EC}, \mathrm{OC}, \mathrm{PM}_{10}(\mathrm{~S})$ & (c), (i) \\
\hline Melpitz [DE44] & Germany & 51.53 & 12.93 & 87 & $\mathrm{EC}, \mathrm{OC}, \mathrm{PM}_{10}, \mathrm{PM}_{2.5}$ & (c) \\
\hline Payerne [CH02] & Switzerland & 46.81 & 6.94 & 510 & $\mathrm{EC}, \mathrm{OC}, \mathrm{PM}_{2.5}, \mathrm{AMS}$ & (c), (i) \\
\hline Montelibretti [IT01] & Italy & 42.10 & 12.63 & 48 & $\mathrm{EC}, \mathrm{OC}, \mathrm{PM}_{10}, \mathrm{PM}_{2.5}$ & (c) \\
\hline Montseny [ES1778] & Spain & 41.77 & 2.35 & 700 & $\mathrm{EC}(\mathrm{S}), \mathrm{OC}(\mathrm{S}), \mathrm{TC}(\mathrm{W}), \mathrm{PM}_{10}$ & (c) \\
\hline Hurdal [HUR] & Norway & 60.37 & 11.07 & 300 & $\mathrm{EC}, \mathrm{OC}, \mathrm{S}-\mathrm{A}, \mathrm{PM}_{1}$ & (e) \\
\hline Oslo [OSL] & Norway & 59.93 & 10.73 & 77 & $\mathrm{EC}, \mathrm{OC}, \mathrm{S}-\mathrm{A}, \mathrm{PM}_{1}$ & (e), (h) \\
\hline Gothenburg [GOT] & Sweden & 57.72 & 11.97 & 20 & $\mathrm{EC}, \mathrm{OC}, \mathrm{S}-\mathrm{A}, \mathrm{PM}_{10}(\mathrm{~W}), \mathrm{PM}_{2.5}(\mathrm{~S})$ & (f), (h) \\
\hline Råö [SE14] & Sweden & 57.39 & 11.91 & 10 & $\mathrm{EC}, \mathrm{OC}, \mathrm{S}-\mathrm{A} \mathrm{PM} 2.5(\mathrm{~W})$ & (f) \\
\hline
\end{tabular}

Notes: $\uparrow$ S-A indicates data for source-apportionment, see below; (S) indicates summer, (W) indicates winter; (a) CARBOSOL campaign, July 2002-September 2004, used weekly filter measurements of EC, OC, cellulose, levoglucosan, and (for seasonally-pooled samples) ${ }^{14} \mathrm{C}$, see Gelencsér et al. (2007), Pio et al. (2007); (b) EMEP EC/OC campaign, 1 July 2002-1 July 2003, 24h filter measurements of EC and OC, once per week, see Yttri et al. (2007); (c) EMEP PM intensive campaign June 2006(S) and 8 January-4 February 2007(W), many different measurements were performed in the campaign, see Yttri et al. (2008), Aas et al. (2012). Here we use daily data from filter measurements of EC and OC and hourly AMS (OM) data from Payerne for the summer period; (d) For Birkenes filter measurement data for EC and OC in PM 10 were available from EMEP for the full years 2002-2004. The data were either weekly measurements or alternatingly 6-days and 24h measurements; (e) SORGA campaign, southern Norway, 19 June-15 July 2006(S) and 1-8 March 2007(W), included filter measurements of EC, OC, sugars, levoglucosan, and ${ }^{14} \mathrm{C}$, (Yttri et al., 2011), here we use the $\mathrm{PM}_{1}$ data and compare to the model $\mathrm{PM}_{2.5}$ results; (f) Göte-2005 campaign, southern Sweden, 11 Feburary-4 March 2005 (W) and 13 June-4 July 2006 (S), included measurements of EC, OC, sugars, levoglucosan, and ${ }^{14}$ C, (Szidat et al., 2009); (g) Mountain station; (h) Urban background station; (i) Hourly observation data were available, averaged here to daily means (except for the AMS data, that were averaged to hourly means).

with nine bins, is used for the directly emitted organic aerosol components (of low to intermediate volatility, that is, in particulate as well as gaseous form) from fossil fuel use, residential wood combustion and vegetation fires, to cover the great range of different volatilities of these species (Robinson et al., 2007; Shrivastava et al., 2008).

The temperature dependence of the gas-particle partitioning is taken into account by using the Clausius-Clapeyron equation to calculate the saturation concentrations, along

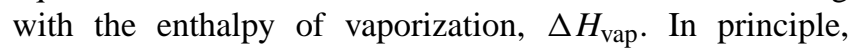
$\Delta H_{\text {vap }}$ should vary across the VBS bins, with higher values for the lower $C^{*}$ values (Epstein et al., 2010). In this study we use the $\Delta H_{\text {vap }}$-values from Robinson et al. (2007), for the nine-bin VBS used for the primary emissions (values vary from $64 \mathrm{~kJ} \mathrm{~mol}^{-1}$ for the most volatile bin to $112 \mathrm{~kJ} \mathrm{~mol}^{-1}$ for the least volatile). The VBS-parameterisation of SOA yields from Pathak et al. (2007) used a constant effective $\Delta H_{\text {vap }}=30 \mathrm{~kJ} \mathrm{~mol}^{-1}$, for the four-bin VBS. This value was selected to reproduce the observed temperature dependence of the smog chamber aerosol yields and accounts for various temperature effects on the SOA yields. Here we use this effective $\Delta H_{\text {vap }}$ for the SOA from VOC (similar to e.g. Lane et al., 2008a,b; Murphy and Pandis, 2009; Farina et al., 2010).

Four versions of the EMEP model have been set up, introducing different aspects of the VBS approach in each version and testing various assumptions about aging reactions of OA-components in the gas phase. The model versions are summarised in Table 3, and discussed below.

In all model versions, BSOA formation from terpenes is initiated by gas phase oxidation by $\mathrm{O}_{3}, \mathrm{OH}$ or $\mathrm{NO}_{3}$ in the model. For isoprene, only oxidation by $\mathrm{OH}$ leads to BSOA formation. As noted in Sect. 2.1.1, we only include isoprene and mono-terpenes among the biogenic species, and not sesquiterpenes. Initial OM/OC ratios are assumed to be 1.7 for BSOA from terpenes and 2.0 for isoprene BSOA (based on Chhabra et al., 2010). In the following, we will denote SOA formed from anthropogenic emissions of VOC from fossil sources ("traditional" ASOA) as $\mathrm{ASOA}_{\mathrm{f}}^{\mathrm{V}}$. For $\mathrm{ASOA}_{\mathrm{f}}^{\mathrm{V}}$ from alkanes and alkenes $\mathrm{OM} / \mathrm{OC}=1.7$ is used and for $\mathrm{ASOA}_{\mathrm{f}}^{\mathrm{V}}$ from aromatic VOCs the ratio is 2.1 (Chhabra et al., 2010).

It should be stressed that we regard all of these versions as experiments, in order to demonstrate the importance of 
Table 3. Summary of the four EMEP model versions used in this study.

\begin{tabular}{llll}
\hline Version & $\begin{array}{l}\text { Volatility } \\
\text { distributed POA? }\end{array}$ & $\begin{array}{l}\text { S/IVOC/SOA aging } \\
\text { reactions }\end{array}$ & References \\
\hline NPNA & No, POA nonvolatile & None & Lane et al. (2008a); Tsimpidi et al. (2010) \\
\hline PAP & Yes & S/IVOC $\left(4.0 \times 10^{-11} \mathrm{~cm}^{3} \mathrm{molecule}^{-1} \mathrm{~s}^{-1}\right)$ & Shrivastava et al. (2008) \\
\hline PAPA & Yes & $\begin{array}{l}\text { S/IVOC }\left(4.0 \times 10^{-11} \mathrm{~cm}^{3} \mathrm{molecule}^{-1} \mathrm{~s}^{-1}\right), \\
\text { ASOA }\end{array}$ & Murphy and Pandis (2009); Tsimpidi et al. (2010) \\
\hline PAA & Yes & $\begin{array}{l}\text { S/IVOC }\left(4.0 \times 10^{-11} \mathrm{~cm}^{3} \mathrm{molecule}^{-1} \mathrm{~s}^{-1}\right) \\
\text { ASOA }_{\mathrm{f}}^{\mathrm{V}} \& \text { BSOA }\left(4.0 \times 10^{-12} \mathrm{~cm}^{3} \mathrm{molecule}^{-1} \mathrm{~s}^{-1}\right)\end{array}$ & Lane et al. (2008b) \\
\hline
\end{tabular}

the various VBS assumptions, and to assess how far such approaches can capture observed levels of OM. Sect. 6 will discuss some of the limitations of VBS assumptions in particular, and of SOA modelling in general.

\subsection{NPNA VBS method}

The first model version, NPNA (No Partitioning of primary emissions and No Aging reactions included), is based on the SOA scheme of Lane et al. (2008a), for SOA formation from anthropogenic and biogenic VOC (AVOC and BVOC) (although Lane et al. 2008a also included SOA formation from sesquiterpenes).

The SOA yields are updated to take into account recent findings about higher yields from oxidation of aromatic VOCs (Hildebrandt et al., 2009; Ng et al., 2007a; Tsimpidi et al., 2010). The SOA yields are summarised in Table 4.

In the NPNA model version, primary organic aerosol emissions (including wood burning and vegetation fire OM emissions) are assumed non-volatile, taken directly from the carbonaceous aerosol emission data-sets.

\subsection{PAP VBS method}

The PAP (Partitioning and atmospheric Aging of Primary semi- and intermediate-volatility OC emissions) model introduces three important changes to the treatment of the primary organic aerosol emissions and atmospheric chemistry, following suggestions of Shrivastava et al. (2008):

i. The emitted POA is distributed over different volatilities (9-bin VBS, including semi-volatile and intermediate volatility OC, S/IVOC) and partitions between the gas and particulate phases. This allows a large fraction of the POA to evaporate.

ii. The POA emissions are assumed to be accompanied by emissions of intermediate volatility (IVOC) gases, which are currently not captured in either the POA or the VOC inventories. Following Shrivastava et al. (2008) we assume that the total emissions of S/IVOCs (including low-volatile POA) amount to 2.5 times the POA inventory. This means that an IVOC mass of 1.5 times the POA emissions is added to the total emission input in the model. We use the same emission split and enthalpies of vaporization as in Shrivastava et al. (2008) to calculate how much of this material is condensed at any moment. A large part, $68 \%$, of the primary S/IVOC emission consists of IVOCs with $C^{*}$ ranging from $10^{4}$ to $10^{6} \mu \mathrm{g} \mathrm{m} \mathrm{m}^{-3}$.

iii. The emitted S/IVOCs are allowed to react with $\mathrm{OH}$ in the gas phase, with each reaction resulting in a shift of the compound to the next lower volatility bin. The $\mathrm{OH}$-reaction rate used in this study, $4.0 \times 10^{-11} \mathrm{~cm}^{3}$ molecule ${ }^{-1} \mathrm{~s}^{-1}$, is taken from Robinson et al. (2007) and corresponds to the base case in Shrivastava et al. (2008). As in Robinson et al. (2007) and Shrivastava et al. (2008), we assume a small mass increase $(7.5 \%)$ with each aging reaction to account for added oxygen atoms. In this paper we will use the notation $\mathrm{SOA}^{\mathrm{SI}}$ for secondary organic aerosol formed by atmospheric oxidation of the S/IVOC emissions. SOA ${ }^{\text {SI }}$ from anthropogenic fossil fuel sources will be denoted $\mathrm{ASOA}_{\mathrm{f}}^{\mathrm{SI}}$.

\subsection{PAA VBS method}

In the PAA version (Partitioning of primary OA and Aging of All semivolatile OA components in the gas phase) aging reactions for SOA-components in the gas phase are also included with the same assumption of each reaction leading to a lowering of the volatilities of these species by a factor of ten and a net mass increase by $7.5 \%$ to account for added oxygen. The $\mathrm{OH}$-reaction rate for SOA-aging $\left(4.0 \times 10^{-12}\right.$ $\mathrm{cm}^{3}$ molecule $\mathrm{s}^{-1} \mathrm{~s}^{-1}$ ) is assumed to be an order of magnitude lower than for the S/IVOCs (as suggested by Lane et al., 2008b).

Lane et al. (2008b) showed that including aging reactions for SOA leads to serious overestimation of OC concentrations in rural areas in eastern USA. They suggest that although aging reactions for SOA components do occur, the effect may not be a net increase in particle mass since decomposition reactions may compete with substitution reactions. In the polluted Mexico City region, with large primary OA 
Table 4. Mass yields of the semi-volatile surrogate species, with $298 \mathrm{~K}$ saturation concentrations of $1,10,100$ and $1000 \mu \mathrm{g} \mathrm{m}^{-3}$, for the EMEP model SOA precursors for the high- and low- $\mathrm{NO}_{\mathrm{x}}$ cases (corresponding to peroxy radical reaction with $\mathrm{NO}_{\text {and }} \mathrm{HO}_{2}$, respectively).

\begin{tabular}{|c|c|c|c|c|c|c|c|c|}
\hline \multirow{3}{*}{ Precursor } & \multicolumn{8}{|c|}{$\alpha$-values (mass based stoichiometric yields) } \\
\hline & \multicolumn{4}{|c|}{ High- $\mathrm{NO}_{\mathrm{x}}$ Case } & \multicolumn{4}{|c|}{ Low- $\mathrm{NO}_{\mathrm{x}}$ Case } \\
\hline & 1 & 10 & 100 & 1000 & 1 & 10 & 100 & 1000 \\
\hline Alkanes & 0 & 0.038 & 0 & 0 & 0 & 0.075 & 0 & 0 \\
\hline Alkenes & 0.001 & 0.005 & 0.038 & 0.15 & 0.005 & 0.009 & 0.060 & 0.225 \\
\hline Aromatics & 0.002 & 0.195 & 0.3 & 0.435 & 0.075 & 0.3 & 0.375 & 0.525 \\
\hline Isoprene & 0.001 & 0.023 & 0.015 & 0 & 0.009 & 0.03 & 0.015 & 0 \\
\hline Terpenes & 0.012 & 0.122 & 0.201 & 0.5 & 0.107 & 0.092 & 0.359 & 0.608 \\
\hline
\end{tabular}

Notes: yields are based on Tsimpidi et al. (2010), and references therein. Alkanes (excluding $\mathrm{C}_{2} \mathrm{H}_{6}$ ), alkenes (excluding $\mathrm{C}_{2} \mathrm{H}_{4}$ ) and aromatics are represented by the surrogates n-butane, propene, $\mathrm{o}$-xylene in the EMEP chemistry.

emissions, even the aging of the primary S/IVOC emissions in a PAP-like VBS-model may lead to significant overestimation of SOA, which was recently shown by Shrivastava et al. (2011).

\subsection{PAPA VBS method}

Murphy and Pandis (2009) include aging reactions for the primary OA and S/IVOC and anthropogenic SOA but not for biogenic SOA. In this study we test this assumption in the PAPA version (Partitioning and Aging of Primary OA and Anthropogenic SOA), using the aging rates suggested by Murphy and Pandis (2009), $4.0 \times 10^{-11} \mathrm{~cm}^{3}$ molecule ${ }^{-1} \mathrm{~s}^{-1}$ for S/IVOC and $1.0 \times 10^{-11} \mathrm{~cm}^{3}$ molecule ${ }^{-1} \mathrm{~s}^{-1}$ for $\mathrm{ASOA}_{\mathrm{f}}^{\mathrm{V}}$. We make the same assumption about additional oxygen mass due to aging reactions in the PAPA model version as in the PAP and PAA versions. This means that the PAPA model is very similar to the VBS-scheme used by Tsimpidi et al. (2010) (Murphy and Pandis 2009 treated the additional oxygen due to aging differently).

\section{Results}

\subsection{Total organic aerosol in $\mathbf{P M}_{2.5}$}

Figure 3 shows calculated total organic mass in $\mathrm{PM}_{2.5}$ $\left(\mathrm{OM}_{\mathrm{PM}_{2.5}}\right)$ concentrations with the four different model variants (six-year average for the whole period 2002-2007).

In the simplest model version (NPNA), with no aging of the aerosol, and the primary OA emissions treated as nonvolatile, the calculated OM concentrations are low in large parts of Europe. The OM distribution reflects the emission inventory with the highest concentrations in France, Russia, Latvia and a region in Central Europe (the Czech Republic, Slovakia and southern Poland). A few other hotspots with high concentrations are also seen; most notably Oslo (Norway), Istanbul/Bosphorus Strait, northern Portugal and point sources in Ukraine.
When the primary emissions are treated in the VBS, and are subject to evaporation and aging reactions (PAP), the picture changes and the concentrations are more homogeneous across Europe. OM concentrations in the hotspots are decreased (in spite of the increase in total POA emitted in the PAP model), due to evaporation of part of the POA emissions. The levels further away from the main emission areas are increased due to the aging reactions that decrease the volatility of the semi-volatile OC. Eastern and Central Europe, as well as parts of France, the Po Valley and the Oslo region, have the highest OM concentrations (above $3 \mu \mathrm{g} \mathrm{m}^{-3}$ ).

Adding aging reactions also for the SOA (PAPA and PAA models) increases the calculated OM concentrations further. In the model version including aging of BSOA (PAA) the model OM is above $3 \mu \mathrm{g} \mathrm{m}^{-3}$ in large parts of Europe (the main exceptions are the British Isles and the northern part of Scandinavia and Russia that have low concentrations of organic aerosol). OM concentrations above the Mediterranean and Black Seas are elevated in the PAPA and PAA models. This accumulation over the sea areas is likely due to fairly high concentrations of $\mathrm{OH}$ in these regions, leading to high oxidation rates for the semi-volatile OA components in the gas phase, and little precipitation, which means small deposition losses.

The realism of these concentration levels is considered in relation to measurements, and in more general terms, in Sect. 5.4 and Sect. 6.

\subsection{Contributions from different sources to organic aerosol in Europe}

In Fig. 4 (and Figs. S2-S4) the calculated relative contributions to $\mathrm{OM}_{\mathrm{PM}_{2.5}}$ from different sources are compared. Although it is not clear which model version can be considered most realistic we choose to show results for the PAA version here, since it gives the highest modelled $\mathrm{OM}_{\mathrm{PM}_{2.5}}$ and includes more atmospheric processing of the OA than the other versions (results for the other versions are given in the 


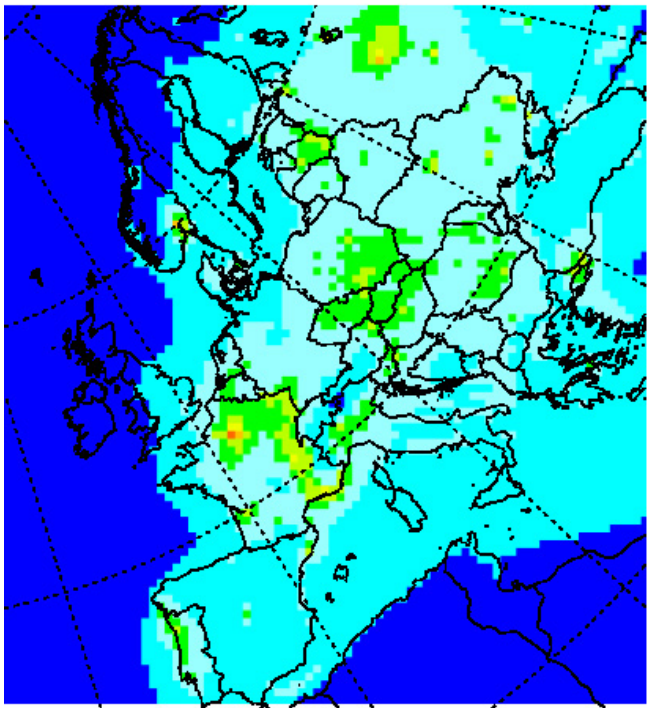

(a) NPNA

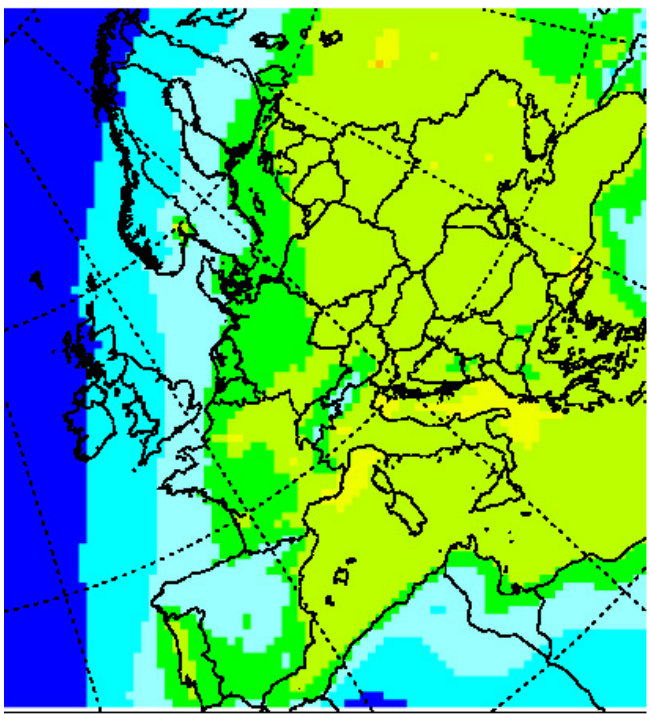

(c) PAPA

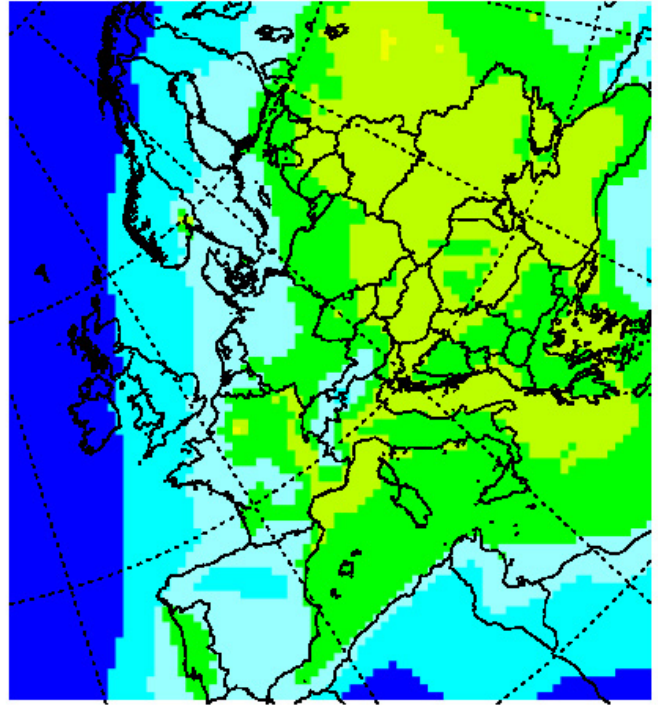

(b) PAP

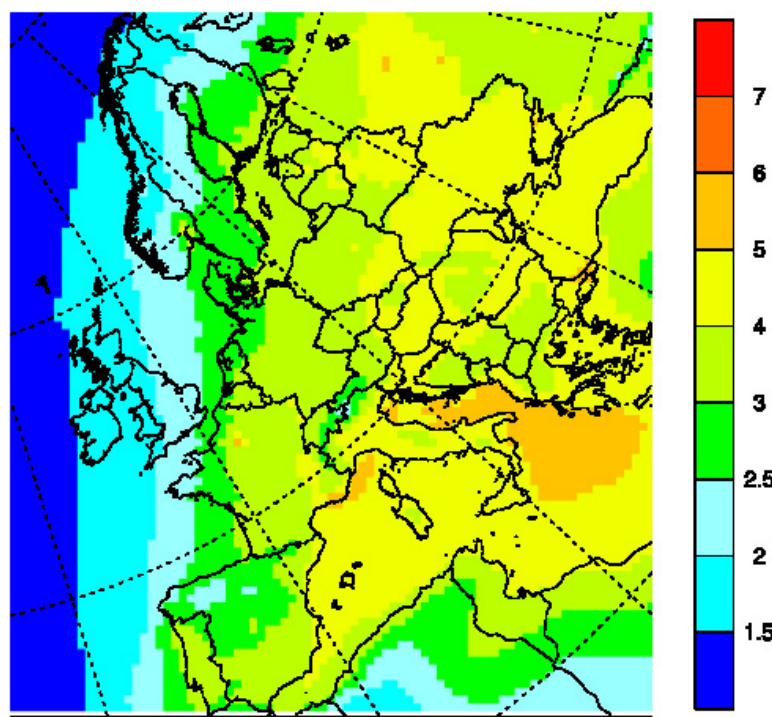

(d) PAA

Fig. 3. Total Organic Matter in $\mathrm{PM}_{2.5}\left(\mathrm{OM}_{\mathrm{PM}_{2.5}}\right)$. 6-yr average concentration (for the period 2002-2007) calculated with the EMEP-PCM model. Comparison between four different model versions (see text). Unit: $\mu \mathrm{g} \mathrm{m}^{-3}$.

Supplement, and in more detail, for selected sites, in Fig. 5a, b and S5-S6).

Several different sources contribute significantly to the modelled $\mathrm{OM}_{\mathrm{PM}_{2.5}}$. Biogenic SOA is an important component; in parts of Finland and Spain and the Mediterranean region the BSOA contribution to $\mathrm{OM}_{\mathrm{PM}_{2.5}}$ is above $30 \%$ in the PAA version, which has the highest BSOA levels, because of the aging reactions of semi-volatile biogenic species. In model versions that do not include atmospheric aging of BSOA the importance of this source is much lower (below $20 \%$ in most of Europe, see Figs. S2-S4).
The importance of anthropogenic SOA from fossil sources $\left(\mathrm{ASOA}=\mathrm{ASOA}_{\mathrm{f}}^{\mathrm{V}}+\mathrm{ASOA}_{\mathrm{f}}^{\mathrm{SI}}\right)$ is very sensitive to assumptions regarding the aging reactions in the atmosphere. In the simplest model version (NPNA, Fig. S2), which only includes traditional ASOA from AVOC and no atmospheric aging, the contribution to $\mathrm{OM}_{\mathrm{PM}_{2.5}}$ is below $10 \%$ in all of Europe. All other model versions include the formation of $\mathrm{ASOA}_{\mathrm{f}}^{\mathrm{SI}}$ from the primary S/IVOC emissions and this gives more than $10 \%$ ASOA in most of Europe; only the northern part has less ASOA. When atmospheric aging of (traditional) $\mathrm{ASOA}_{\mathrm{f}}^{\mathrm{V}}$ is also included (PAA and PAPA models) 


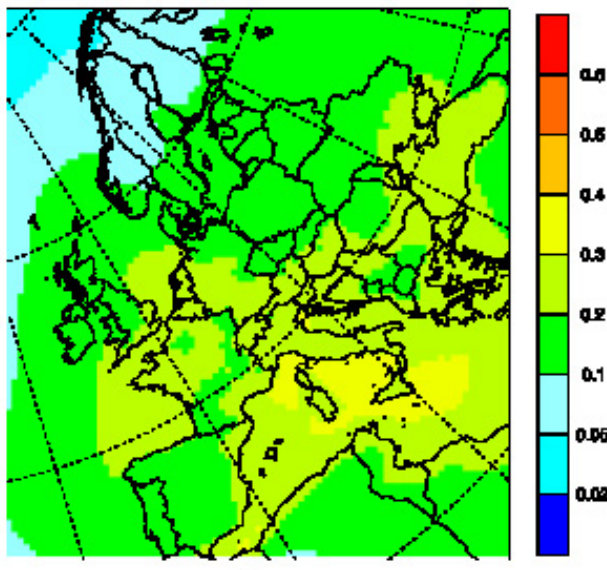

(a) ASOA

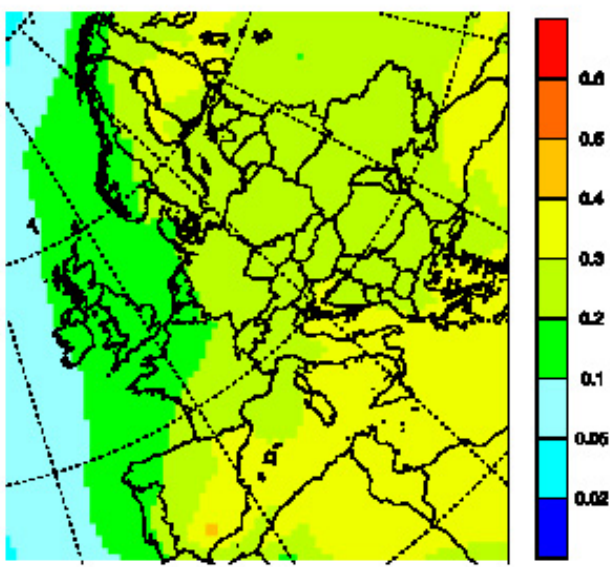

(c) $\mathrm{BSOA}$

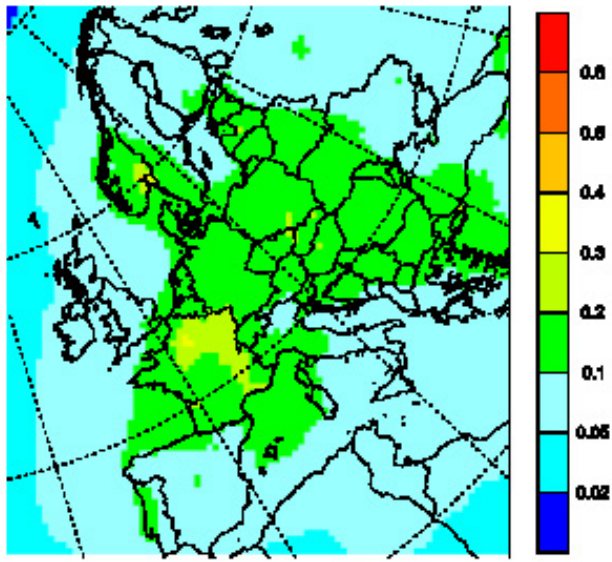

(e) Residential Wood Burning OA

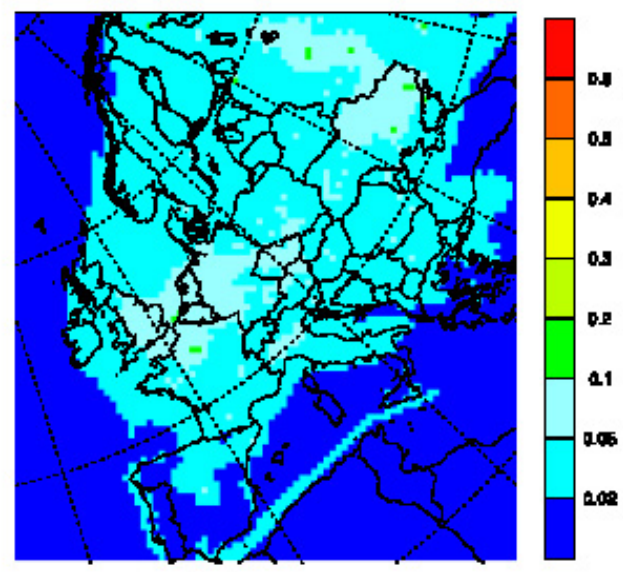

(b) Fossil POA

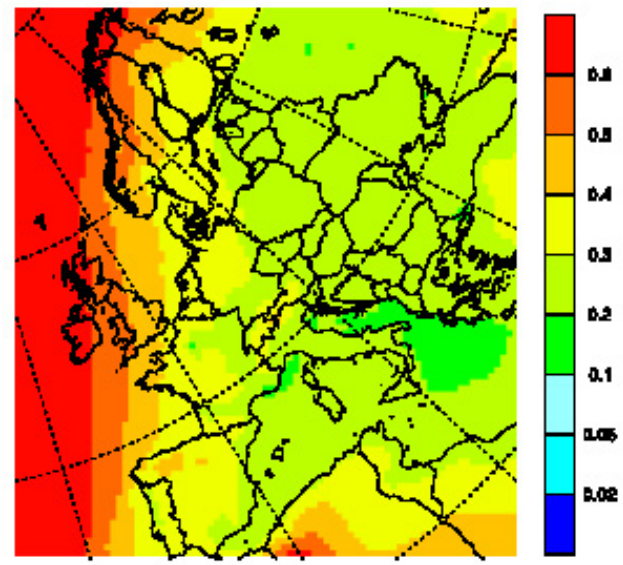

(d) Background $\mathrm{OA}$

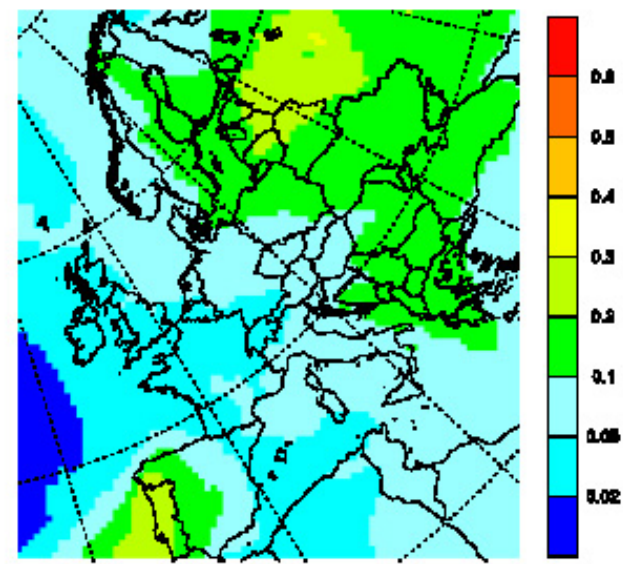

(f) Vegetation Fire $O A$

Fig. 4. Calculated relative contribution to organic matter in $\mathrm{PM}_{2.5}\left(\mathrm{OM}_{\mathrm{PM}_{2.5}}\right)$ from different sources, using the PAA model version. Fraction of $\mathrm{OM}_{\mathrm{PM}_{2.5}}$ from (a) anthropogenic SOA (from AVOC and fossil fuel S/IVOC, i.e., ASOA $\mathrm{f}+\mathrm{ASOA}_{\mathrm{f}}^{\mathrm{SI}}$ ), (b) fossil fuel primary organic aerosol (POA), (c) biogenic SOA (from BVOC), (d) background organic aerosol (from sources not explicitly included in the model), (e) residential wood combustion (primary $+\mathrm{SOA}^{\mathrm{SI}}$ ), (f) vegetation fires (primary $+\mathrm{SOA}^{\mathrm{SI}}$ ). Average for the 6-yr period $2002-2007$. 


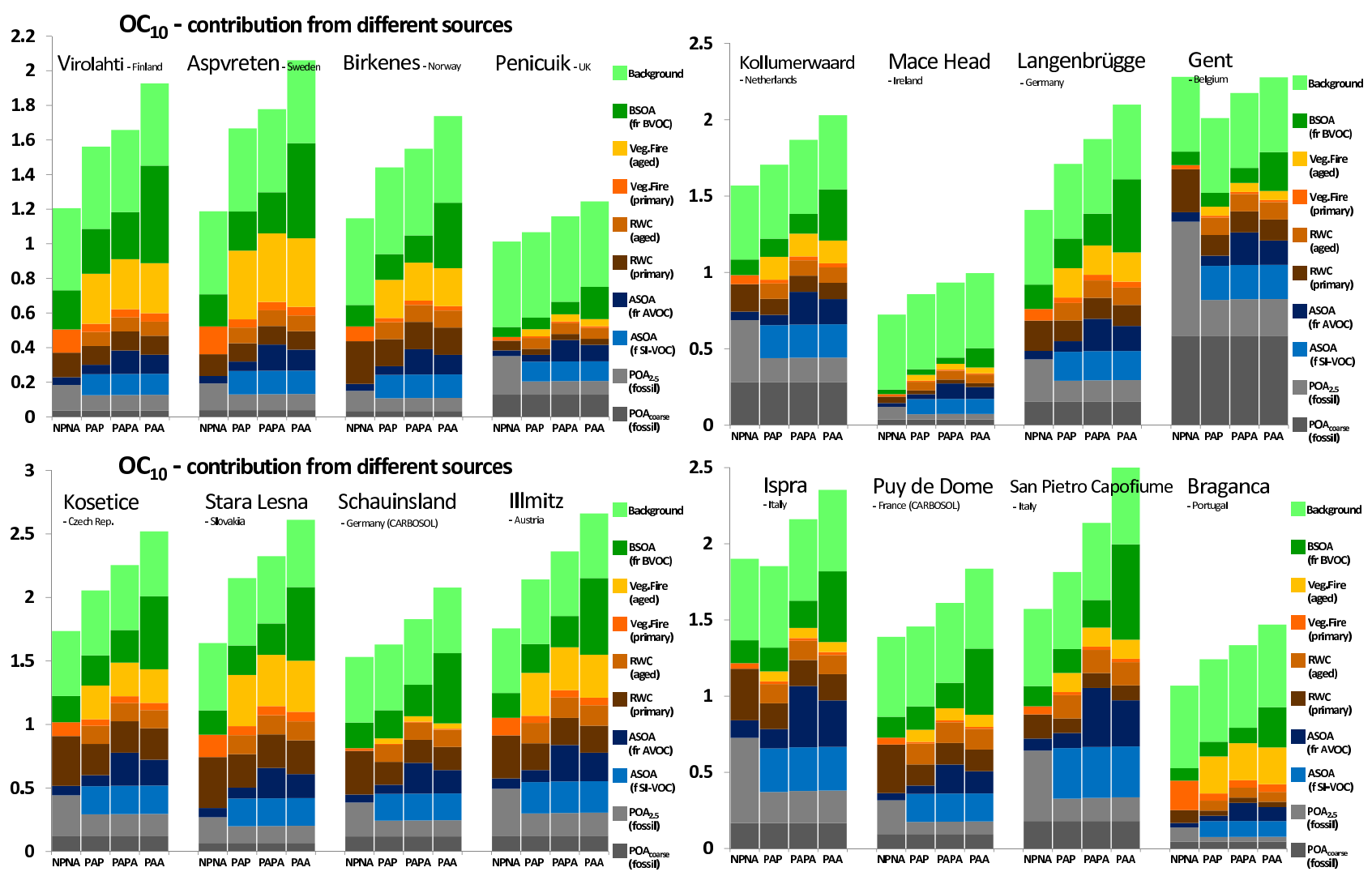

Fig. 5. Modelled contribution from different sources to $\mathrm{OC}_{\mathrm{PM}_{10}}$, at sites from the EMEP EC/OC campaign 2002-2003 and the CARBOSOL project, arranged from north to south. Long-term averages for the different model versions (NPNA, PAP, PAPA and PAA, see text). For most sites the data are averages for the period July 2002-June 2003 but for the two stations Schauinsland and Puy de Dome (from the CARBOSOL project), the averages are for October 2002-September 2004. Colours/Notation, Dark grey: primary OA in PM $2.5-10$ (coarse mode); Light grey: primary OA in $\mathrm{PM}_{2.5}$; medium blue: anthropogenic SOA from aged S/IVOC emissions; dark blue: anthropogenic SOA from VOC; dark brown: primary OA from Residential Wood Combustion (RWC); Light brown: aged OA from RWC S/IVOC emissions; orange: primary OA from vegetation fires (open-burning wildfires and agricultural fires); light orange: aged OA from vegetation fires; dark green: biogenic SOA from terpenes and isoprene; light green: background OA, from sources not included in the model.

the importance of ASOA is further enhanced. In the PAPA model, with a high rate for the $\mathrm{ASOA}_{\mathrm{f}}^{\mathrm{V}}$ aging, the model ASOA fraction of the total $\mathrm{OM}_{\mathrm{PM}_{2.5}}$ is $40-50 \%$ over most of the Mediterranean Sea and in the Po Valley. This is due to high $\mathrm{OH}$-concentrations, low deposition over the sea and (in some parts) high VOC emissions; in such conditions the PAPA model gives a very high SOA yield for emitted aromatic VOCs (sometimes approaching $100 \%$, at least during summer), much larger than those found in smog-chamber studies by $\mathrm{Ng}$ et al. (2007a). This issue is discussed further in Sect. 6.

For the period 2002-2007, vegetation fires seem to be a major source of $\mathrm{OM}_{\mathrm{PM}_{2.5}}$ in some parts of Europe, most notably Russia and eastern Europe and Portugal and western Spain. In these regions more than $10 \%$ of the long-term average $\mathrm{OM}_{\mathrm{PM}_{2.5}}$ may be due to vegetation fire emissions. However, if the emissions are treated as nonvolatile and not ag- ing in the atmosphere the impacts are much more local (see Fig. S2).

In the PAA-model the primary (fresh) fossil fuel OA contribution to $\mathrm{OM}_{\mathrm{PM}_{2.5}}$ is relatively low in most of Europe, ranging from $2-10 \%$, and even lower in parts of southern Europe (due to evaporation and rapid loss of POA compounds by oxidation). In some emission hot-spots (e.g. Paris and Moscow) the contribution is $10-20 \%$.

If the primary emissions are treated as nonvolatile (NPNAversion, Fig. S2) the fresh POA fraction of the total OA is much higher; in this version there is no evaporation of the emitted POA in the emission regions, which leads to high contributions in the major source areas.

We find relatively large contributions of residential wood burning to $\mathrm{OM}_{\mathrm{PM}_{2.5}}$, above $10 \%$ in large parts of Europe in all model versions.

In Fig. 5a, b (and S5-S6) the contribution of the different sources to OC are shown in more detail for different sites in 


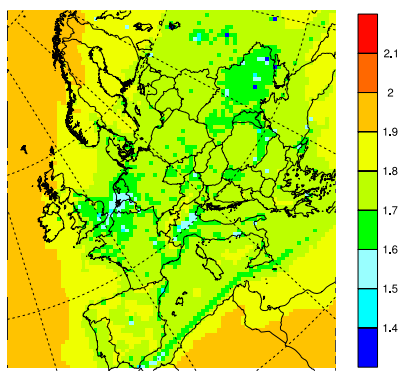

(a) VBS-NPNA

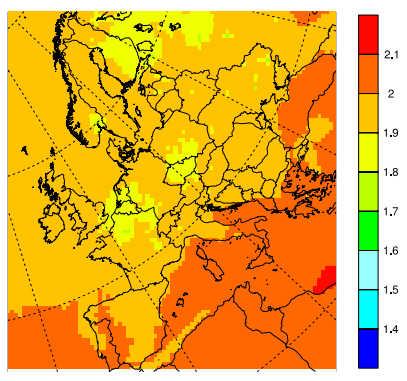

(b) VBS-PAPA
Fig. 6. Model calculated OM/OC ratio in $\mathrm{PM}_{2.5}$ with two of the model versions, NPNA giving the lowest ratios and PAPA giving the highest. Average OM/OC for the whole 6-yr period 2002-2007.

Europe (sites to be discussed in Sect. 5.4), including separate contributions from primary and secondary organic aerosol. The importance of the individual sources vary from site to site and there are important differences between winter and summer (Figs. S5-S6):

- The traditional SOA components (BSOA and ASOA from VOCs) are important during the summer months but other sources also contribute during these periods, especially fossil OC from primary emissions, $\mathrm{POA}+\mathrm{SOA}$ from S/IVOC-emissions $\left(\mathrm{ASOA}_{\mathrm{f}}^{\mathrm{SI}}\right)$, is important at many locations (most of it is $\operatorname{ASOA}_{\mathrm{f}}^{\mathrm{SI}}$ in the model versions that includes S/IVOC emissions).

- As will be discussed in more detail in Sect. 5.5, the PAA code (that includes aging of BSOA) predicts the highest BSOA levels (and has values of these lying closest to the observation-derived values, at least for summer periods). In the other model versions, that do not include atmospheric aging of the semi-volatile BSOA, the OCcontributions from this source is much less important.

- Vegetation fires are also very important sources of $\mathrm{OC}_{\mathrm{PM}_{10}}$ during certain episodes. The importance of the fires is larger in the model versions PAP, PAPA and PAA, that assume that the wildfire POA emissions are accompanied by additional S/IVOC emissions that later oxidise in the atmosphere to form $\mathrm{SOA}^{\mathrm{SI}}$, than in the version NPNA, that treats all emissions as completely non-volatile. The relative difference between the different treatments is smallest for the site that is located closest to the emission source (Braganca) and increase with the distance to the fires.

- For the urban background sites Gent and San Pietro Capofiume as well as for the rural site Penicuik (near Edinburgh) and the regional background site Kollumerwaard in the Netherlands, the fossil fuel OC is a major source of $\mathrm{OC}_{\mathrm{PM}_{10}}$ most of the time.
- Residential wood burning is an important source at most sites during winter and early spring. In contrast to the vegetation fire $\mathrm{OC}$, the total contributions to $\mathrm{OC}_{\mathrm{PM}_{10}}$ from residential wood combustion, at most of the sites studied here, do not change very much depending on whether the emissions are treated as completely non-volatile (NPNA) or as being partially semi-volatile and accompanied by additional IVOC-emissions (PAP, PAPA, PAA).

\section{$5.3 \mathrm{OM} / \mathrm{OC}$ ratios}

The ratio of total organic mass to organic carbon (OM/OC) is an important property of the organic aerosol. The OM/OC ratio is often used to estimate total $\mathrm{OM}$ in $\mathrm{PM}_{2.5}$ from measured $\mathrm{OC}$ concentrations. A value of $\mathrm{OM} / \mathrm{OC}=1.4$ has often been used, although Turpin and Lim (2001) showed that $\mathrm{OM} / \mathrm{OC}$ ratios are usually higher than this. OM/OC ratios vary with season and location (e.g. Simon et al., 2011). Urban aerosols, dominated by fresh POA emissions, usually have a relatively low OM/OC ratio (e.g. Turpin and Lim, 2001), which increase as the aerosol ages and oxygen is added. Secondary organic aerosol and biomass burning aerosol usually have higher OM/OC ratios than POA (Aiken et al., 2008).

We have calculated long term (2002-2007) average $\mathrm{OM} / \mathrm{OC}$ ratios for Europe and examples of the results are shown in Fig. 6 (and Fig. S7). The ratio depends strongly on the assumptions whether the primary OA emissions are non-volatile and chemically inert or are subject to oxidation (aging) reactions in the atmosphere.

In the NPNA model (Fig. 6a), areas near high POA emissions have relatively low $\mathrm{OM} / \mathrm{OC}$ ratios $(<1.6)$ and in most of Europe the ratio is below 1.9. When chemical aging of S/IVOC and SOA from VOC is included (models PAPA and PAA, Figs. 6b and Fig. S7d) most of Europe has OM/OC ratios above 1.9; for the Mediterranean and parts of southern Europe even above 2.0; the OM/OC ratios are below 1.8 only in a few high emission areas. The model version with aging of only S/IVOC (PAP, Fig. S7b) gives ratios in between; most of central and northern Europe have OM/OC ratios in the 1.8-1.9 range with this model version, outside this region the range is 1.9-2.0, except in some urban hotspots where it is lower.

\subsection{Comparison with long-term measurements of total carbon (TC) and organic carbon (OC)}

In this section we compare model calculations of total carbon and organic carbon to observations from three different campaigns, the EMEP EC/OC campaign 2002-2003, the CARBOSOL project 2002-2004, and the EMEP PM intensive measurement periods in 2006-2007. The maps in Fig. 3 present average results for the whole 6-yr period (20022007), but there are important seasonal variations. Since the dominant winter and summer sources of particulate carbonaceous matter are different we include some model evaluation 


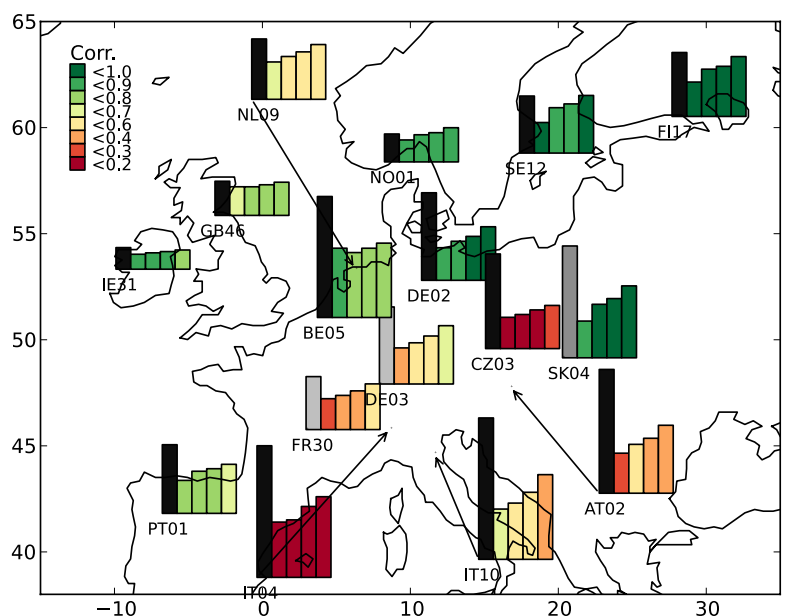

Fig. 7. Observed and modelled $\mathrm{TC}_{\mathrm{PM}_{10}}$ during the summer halfyear period (May-October) at different European sites from the CARBOSOL (2002-2004) and EMEP EC/OC (2002-2003) campaigns. The leftmost bars show observed average concentrations (black for stations located at less than $600 \mathrm{~m}$ altitude, light gray for sites above $1000 \mathrm{~m}$ and medium gray for stations at $600-1000 \mathrm{~m}$ height) and the following four bars the corresponding model concentrations with the four different model versions (NPNA, PAP, PAPA and PAA). The colours of the model bars illustrate the correlation coefficients, see legend. Some stations are moved for clarity, location indicated with arrows. Note that number of samples varies between stations ( $N=13$ for CZ03, $N \geq 22$ for other sites) - see Table S1 for details and results from other campaigns.

data split into summer and winter half-years (here the summer period is defined as the months May-October).

The results for total carbon in $\mathrm{PM}_{10}$ samples $\left(\mathrm{TC}_{\mathrm{PM}_{10}}\right)$ are illustrated in Figs. 7 (summer) and 8 (winter) and summarised in Table S1 and Figs. S8-S9. Figs. S10-S11 and Table $\mathrm{S} 2$ contain results for $\mathrm{TC}$ in $\mathrm{PM}_{2.5}\left(\mathrm{TC}_{\mathrm{PM}_{2.5}}\right)$.

Since a major part of the total carbon in particulate matter is organic carbon the model results for OC are usually similar to those for TC. For organic carbon the modelled seasonal variations are illustrated in time series plots in Figs. 9a, b, at different locations in Europe, together with measured concentrations from the EMEP EC/OC (2002-2003) and CARBOSOL (2002-2004) campaigns. A detailed comparison of the $\mathrm{OC}_{\mathrm{PM}_{10}}$ model results to observations, including data also from the shorter EMEP intensive measurements periods in 2006 and 2007, is given in Table S3 and results for $\mathrm{OC}_{\mathrm{PM}_{2.5}}$ in Table S4.

Comparing the different model versions there is a clear increase in $\mathrm{TC}_{\mathrm{PM}_{10}}$ (and $\mathrm{OC}_{\mathrm{PM}_{10}}$ ) from the simplest model (NPNA) to the model that includes most aging reactions (PAA), although the increase is more marked in summertime. Model results for summer are generally much better than for winter, e.g., the mean absolute error (MAE) of the model results (based on data from all stations in Table S1) range from 1.4 (PAA) -1.8 (NPNA) $\mu \mathrm{g}(\mathrm{C}) \mathrm{m}^{-3}(43-56 \%)$ for

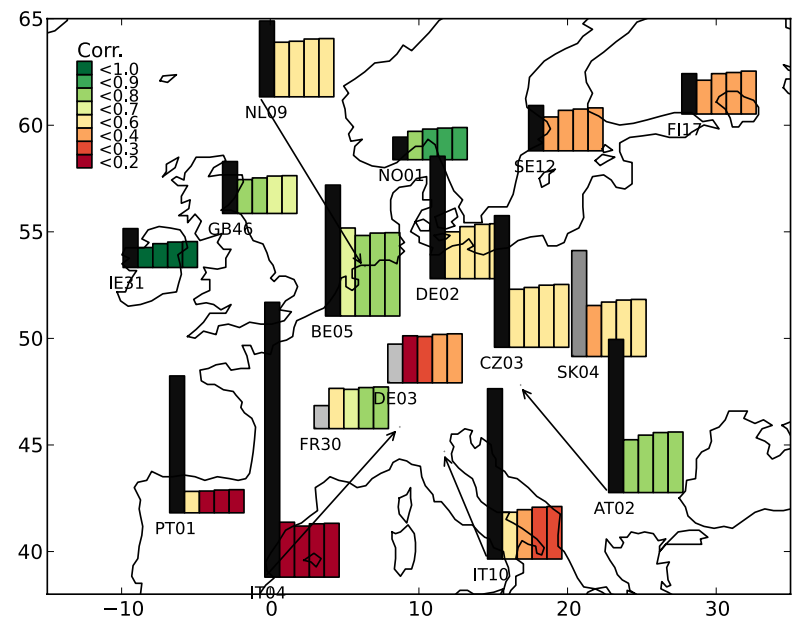

Fig. 8. Observed and modelled $\mathrm{TC}_{\mathrm{PM}_{10}}$ during the winter half-year period (November-April) at different European sites from the CARBOSOL (2002-2004) and EMEP EC/OC (2002-2003) campaigns. Details/Notation see Fig. 7.

summer and about $2.6 \mu \mathrm{g}(\mathrm{C}) \mathrm{m}^{-3}$ (66\%, for all model versions) in winter. Correlation coefficients are also higher for summer, ranging from 0.66 (NPNA) to 0.58 (PAP), than for winter. Results for $\mathrm{OC}_{\mathrm{PM}_{10}}$ are similar (see Table S3).

It should be noted that model performance varies greatly between different sites, partly reflecting their location and representativeness. For the Nordic sites, correlation coefficients for all the model versions are in the range $0.7-0.8$ (for the full-year). The Swedish and Finnish sites (Aspvreten and Virolahti) have very high correlation for summer $(r \sim 0.9)$ but much lower for the winter half-year months (ca. 0.3-0.4); the mean model bias is low at both sites during both winter and summer when the PAA model is used. For the Norwegian station Birkenes correlation coefficients are relatively high both during winter and summer but all model versions overestimate TC and OC during winter. At most other (nonmountain) sites the model underestimates winter concentrations a lot. Outside the northern part of Europe some sites are very poorly described by the model, especially the urbaninfluenced Ispra and San Pietro Capofiume, in Italy, and Braganca in Portugal. For Ispra (summer and winter) and Braganca (winter) the correlation between model and measured $\mathrm{TC}_{\mathrm{PM}_{10}}$ is close to zero and winter time $\mathrm{OC}_{\mathrm{PM}_{10}}$ concentrations are underestimated by a factor of 6 .

The deterioration of model results with increased aging (i.e. more SOA) at the urban-influenced sites in the south is probably a signal that the observations are influenced more by primary emissions than the model suggests. Adding further SOA, which responds very differently to dispersion and chemical processing, only makes such a comparison worse.

The time-series plots of $\mathrm{OC}_{\mathrm{PM}_{10}}$ in Fig. 9a, b illustrate the day-to-day variation in the modelled OC-concentrations. Many of the largest peaks seen at many sites in northern and central Europe (and at Braganca), in the late summer 2002, are totally dominated by contributions from vegetation fires. 
Observations at some sites that are occasionally subject to very clean air, such as the near coastal sites Mace Head (Ireland) and Birkenes (Norway), Aspvreten (Sweden), Kollumerwaard (the Netherlands) and Penicuik (the UK), indicate that the background OC concentration used in the model $\left(0.5 \mu \mathrm{g}(\mathrm{C}) \mathrm{m}^{-3}\right)$ is too high, at least during winter. About $10 \%$ of the winter measurements and about $3 \%$ of the summer measurements of $\mathrm{TC}_{\mathrm{PM}_{10}}$ are lower than $0.5 \mu \mathrm{g}(\mathrm{C}) \mathrm{m}^{-3}$ (see Fig. 9a, b, and S8-S9).

The high-elevation sites are also interesting. In Figs. 7 and 8 , high-elevation sites are indicated by light grey or medium grey bars for the observations, referring to sites at greater than $1000 \mathrm{~m}$ or $600 \mathrm{~m}$ respectively. The $600 \mathrm{~m}$ threshold was chosen somewhat arbitraily, but for example avoids labelling sites such as Kosetice (534 m a.s.1.) as a mountainsite. Rather this site is located in agricultural countryside of the Czech-Moravian Highlands. One would expect the model's surface concentrations (those we use here) to overpredict concentrations at elevated stations. For the winter months this is clearly seen in the time series plots for Puy de Dome and Schainsland, in Fig. 9b; measured concentrations are often very low during winter, indicating that the sites lie above the polluted planetary boundary layer during these periods. However, for summer conditions these sites are much more similar to other central European sites and at least the model version PAA gives $\mathrm{TC}_{\mathrm{PM}_{10}}$ and $\mathrm{OC}_{\mathrm{PM}_{10}}$ in fair agreement with the observed concentrations. Figure 7 shows that the correlation coefficients increase substantially in summertime when SOA formation by aging is included in the model at the high-altitude sites (those indicated with light or darkgray bars for the observations), presumably a signal that SOA formation drives particulate carbon variation in these locations.

There is much less data available for $\mathrm{TC}_{\mathrm{PM}_{2.5}}$ (Figures S10-S11, and Table S2) and $\mathrm{OC}_{\mathrm{PM}_{2.5}}$ (Table S4) than for $\mathrm{TC}_{\mathrm{PM}_{10}}$ and $\mathrm{OC}_{\mathrm{PM}_{10}}$. The conclusions from comparisons of measured and modelled TC and OC concentrations in $\mathrm{PM}_{2.5}$ are similar to those for $\mathrm{PM}_{10}$. Model results for summer are much better than for winter and there is a tendency that the PAA model gives summer concentrations in slightly better agreement with observations than the other model versions do.

For the Italian sites (Ispra and Montelibretti) the differences between summer and winter results for $\mathrm{TC}_{\mathrm{PM}_{2.5}}$ are huge. The PAA model gives reasonably good results for both sites for June 2006 (13 and $29 \%$ underestimation and correlation coefficients of 0.61 and 0.69 , respectively). For the winter period (January-February 2007) the observed $\mathrm{TC}_{\mathrm{PM}_{2.5}}$ of Ispra and Montelibretti were very high (ca. $20 \mu \mathrm{g}(\mathrm{C}) \mathrm{m}^{-3}$ ) and the PAA model results are an order of magnitude lower (the model $\mathrm{TC}_{\mathrm{PM}_{2.5}}$ for the summer period are actually much higher than for the winter period). Dispersion problems could explain some of the wintertime underprediction, but comparisons for other pollutants (e.g. $\mathrm{NO}_{2}$, not shown) at these sites are in much better agreement with observations than we find here for TC. Consistent with other studies (Simpson et al., 2007; Genberg et al., 2011; Denier van der Gon et al., 2012), this points to major problems in the emission inventory (likely the residential wood burning component) for winter emissions, at least in the areas around these sites.

\subsection{Source apportionment studies}

Since the emission input is known by source sector, the model results can be compared to source apportionment (S-A) studies that give information about the relative contributions from different sources to PCM. This may give further indications of the performance of the SOA modules and/or shortcomings of the emission input.

Here we compare model results to three S-A studies which have been analysed with essentially the same methodology: the 2-yr CARBOSOL campaign at sites in central Europe (Gelencsér et al., 2007), the SORGA campaign in the Oslo region in southern Norway (Yttri et al., 2011), and the Göte2005 campaign in and close to Gothenburg in southern Sweden (Szidat et al., 2009). The different studies have split the measured OC and EC into somewhat different components. Table 5 summarises the notation used.

These components and their derivation have been discussed in the three source apportionment studies, most recently by Yttri et al. (2011). Some differences exist in the data available from each study, and in the ratios chosen to translate measurements of the tracer to associated OC amounts, but all used the same basic statistical approach initiated in Gelencsér et al. (2007). Instead of just providing one estimate for the relative contribution of different sources to total carbon, this S-A approach recognises uncertainties in the observed data themselves, and in the relationships between tracers and associated OC. Making use of Latinhypercube-sampling (e.g. McKay et al., 1979) to explore the numerous possible uncertain relationships, a statistical distribution of possible solutions was obtained. We make use of the results as expressed through the percentiles (e.g. 5th, 50th, 95th) of these solutions.

Concerning the SORGA and Göte urban sites (Oslo and Gothenburg), it should be noted that in principle the model resolution is not well suited for urban measurements. Although these cities are relatively small (ca. 0.5 million inhabitants), some underestimation of especially the primary emission components in wintertime should be expected. For example, Szidat et al. (2009) found that TC in central Gothenburg in wintertime was about $1 \mu \mathrm{g} \mathrm{m}^{-3}$ larger than at the nearby rural site $\left(3 \mu \mathrm{g} \mathrm{m}^{-3}\right.$ versus $\left.1.8 \mu \mathrm{g} \mathrm{m}^{-3}\right)$. It is however interesting to compare the results for the two Scandinavian campaigns ${ }^{2}$ : the Oslo and Gothenburg regions are only about $300 \mathrm{~km}$ apart and the cities are also of similar sizes.

\footnotetext{
${ }^{2}$ The S-A data from the SORGA measurements in Norway are from $\mathrm{PM}_{1}$ measurements. The model results are for $\mathrm{PM}_{2.5}$. Most of the $\mathrm{PM}_{2.5}$ mass is expected to be found in $\mathrm{PM}_{1}$ but, especially for
} 

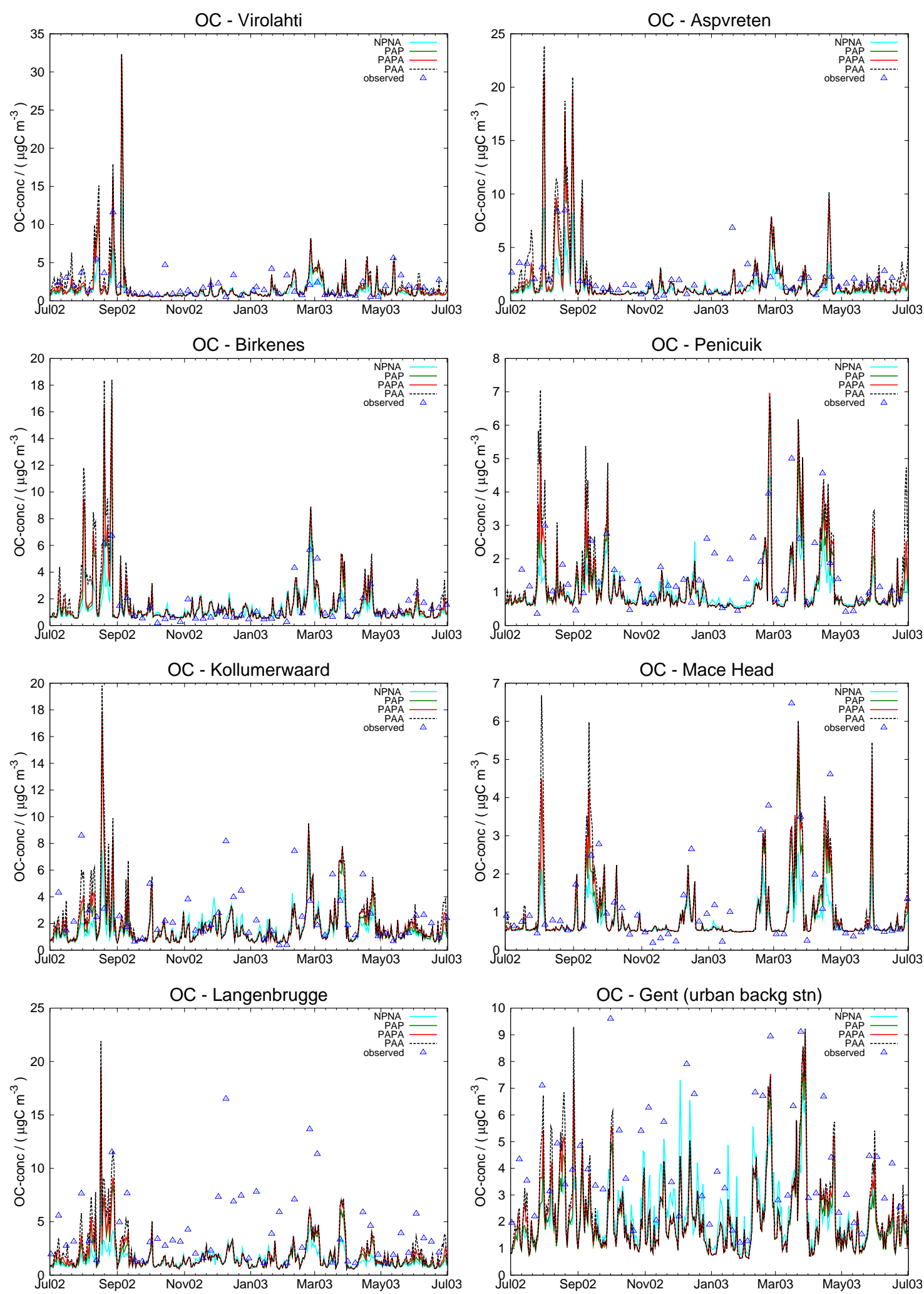

Fig. 9a. Modelled versus observed OC from the EMEP EC/OC campaign 2002-2003, at sites arranged from north to south. Measured total OC-concentrations (24h filter measurements) are indicated with triangles. Units: $\mu \mathrm{g}(\mathrm{C}) \mathrm{m}^{-3}$. 

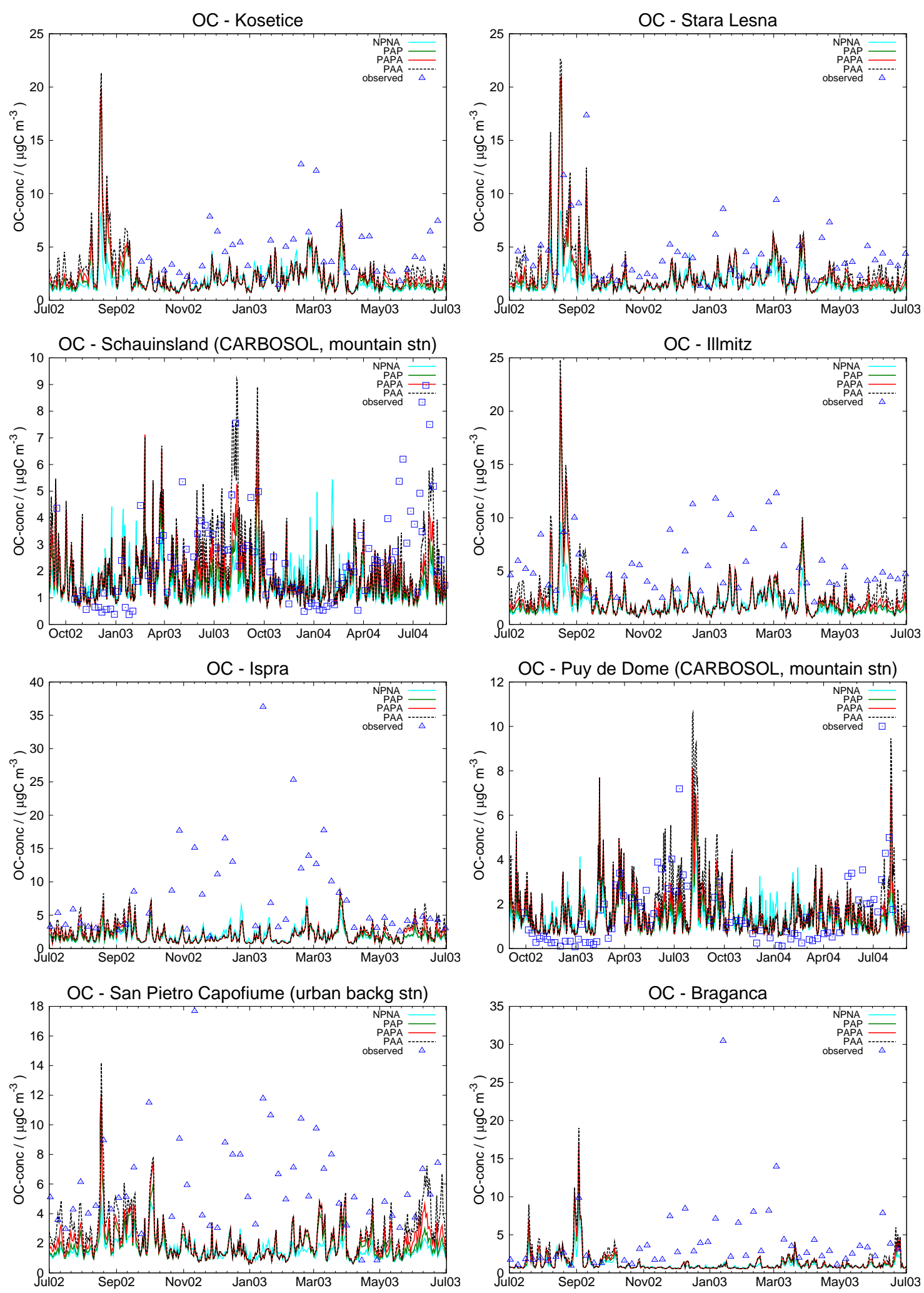

Fig. 9b. For Schauinsland and Puy de Dome observation data (indicated by squares) are weekly filter data from the CARBOSOL project, 2002-2004. Note that both these sites are mountain sites and often above the planetary boundary layer during winter. 
Table 5. Notation for organic aerosol components used in source-apportionment analysis.

\begin{tabular}{|c|c|}
\hline Component & Organic carbon arising from: \\
\hline OC $_{\text {wood }}$ & primary wood-burning OC (from residential combustion and vegetation fires) \\
\hline $\mathrm{OC}_{\mathrm{onf}}$ & $\begin{array}{l}\text { the sum of all non-fossil organic carbon sources other than the primary } \mathrm{OC}_{\mathrm{wood}} \text {, } \\
\text { (e.g. SOA from BVOC and aged S/IVOC from wood-burning, and primary biological } \\
\text { particles); also includes background OC. }\end{array}$ \\
\hline $\mathrm{OC}_{\mathrm{POA}}$ & fossil OC, from primary emissions \\
\hline $\mathrm{OC}_{\mathrm{fASOA}}$ & $\begin{array}{l}\text { anthropogenic SOA from fossil sources } \text { ASOA }_{\mathrm{f}}^{\mathrm{V}}+\mathrm{ASOA}_{\mathrm{f}}^{\mathrm{SI}} \text {, i.e., excluding non-fossil } \\
\text { sources, such as, wood-burning) }\end{array}$ \\
\hline $\mathrm{OC}_{\mathrm{f}}$ & fossil organic carbon, primary or secondary (i.e., $\left.\mathrm{OC}_{\mathrm{POA}}+\mathrm{OC}_{\mathrm{fASOA}}\right)$ \\
\hline
\end{tabular}

\subsubsection{Summer results}

Results for the summer parts of the SORGA and Göte campaigns and CARBOSOL (May-October) project are given in Fig. 10 and Table S5.

Starting with the rural station Hurdal (70 km NE of Oslo), Table S5 and Fig. 10a show that all four model versions predict TC levels $\left(1.2-1.78 \mu \mathrm{g} \mathrm{m}^{-3}\right)$ comparable to the observed value of $1.67 \mu \mathrm{g} \mathrm{m}^{-3}$, with the schemes including most aging being closest in absolute terms. Results for the S-A components vary dramatically though. For $\mathrm{OC}_{\text {wood }}$ (Fig. 10b) the NPNA model overestimates dramatically, whereas the other schemes that assume volatile emissions underestimate. Levels of $\mathrm{OC}_{\text {wood }}$ are, however, low in summer. Other nonfossil contributions to $\mathrm{OC}\left(\mathrm{OC}_{\mathrm{Onf}}\right)$ are much larger and for these three of the four model versions strongly underestimate the observed values, only the PAA scheme which includes aging of BSOA does a good job (Fig. 10c). Total fossil OC; $\mathrm{OC}_{\mathrm{f}}$, spans a range from $0.11-0.26 \mu \mathrm{g} \mathrm{m}^{-3}$ in the observations (Table S5, Fig. 10d), and both the NPNA and PAP schemes fall into this range. The PAPA and PAA schemes with more aging give higher concentrations. Looking at the primary and secondary fractions (Fig. 10e, f), the uncertainty range for the observations is huge, and the model schemes span an equally wide range.

Total Carbon is in fair to good agreement with the observed levels at both Nordic city sites Gothenburg and Oslo, with again the two model versions that include aging reactions for SOA from VOCs (PAPA and PAA) coming closest to observed values. For both cities the model also underestimates the $\mathrm{OC}_{\text {wood }}$ (Fig. 10b) unless the primary emissions are treated as completely non-volatile (NPNA model). As with Hurdal, other non-fossil $\mathrm{OC}$ components $\left(\mathrm{OC}_{\text {onf }}\right)$ are underestimated for both cities unless aging reactions are included for BSOA in the model (PAA), but for Oslo the PAA model gives too high $\mathrm{OC}_{\mathrm{onf}}$. For the summer measurements fossil $\mathrm{OC}\left(\mathrm{OC}_{\mathrm{f}}\right)$ is underestimated in both Gothenburg and Oslo (Fig. 10d), although this is to be expected for a coarse resolution model.

aged aerosol particles, some overestimation can be expected when comparing the model results to the $\mathrm{PM}_{1}$ measurements.
Modelled $\mathrm{EC}_{\mathrm{wood}}$ is rather low in both cities (Table S5), close to the 10th percentile of the S-A analysis. $\mathrm{EC}_{\mathrm{f}}$ is overestimated in Gothenburg, which is somewhat surprising from a large-scale model, and may indicate too high EC-emissions for this region in the used inventory.

For the CARBOSOL sites (Aveiro in Portugal and KPuszta in Hungary) similar patterns are seen. The model underestimates TC levels, and much of this can be traced to an underestimation of the BSOA levels. Unlike for the Nordic sites though, even the PAA scheme cannot produce results in the range of the observed values. Fossil OC is fairly well captured at K-Puszta but underestimated somewhat at Aveiro (Table S5). $\mathrm{EC}_{\text {wood }}$ and $\mathrm{EC}_{\mathrm{f}}$ are well modelled for both sites.

In general, we can conclude that observation-derived $\mathrm{OC}_{\text {onf }}$ in summertime tends to be higher than produced by most of the VBS schemes. The PAA model comes closest to capturing the observed levels; it even overshoots the urban measurements from the Scandinavian campaigns. This should, however, not be taken as proof that the PAA scheme is fundamentally better, as different combinations of BVOC emissions and VBS schemes might well have given similar or even greater levels of BSOA, as we will illustrate in Sect. 5.7. The aging of the semi-volatile OC from the BVOCs in the PAA model is likely to give too large yields of particulate BSOA (with very high aging the model BSOA yield from terpenes can be about $100 \%$ and this is much higher than smog-chamber yields, $\mathrm{Ng}$ et al., 2007b) so the fact that PAA gives $\mathrm{OC}_{\mathrm{Onf}}$ results close to the observed levels may also be an indication that the true BVOC emissions are larger than the ones used here (in terms of magnitude, or missing sources such as sesquiterpenes). The uncertainties involved here are substantial, but given the importance of BSOA to these summertime results there is a great need to constrain/validate the model BVOC emissions in order to better constrain the VBSschemes for BSOA.

\subsubsection{Winter results}

For the winter campaigns (see Fig. 11 and Table S6) model results are remarkably different for the Norwegian and Swedish studies. For the Swedish Göte campaign the model 

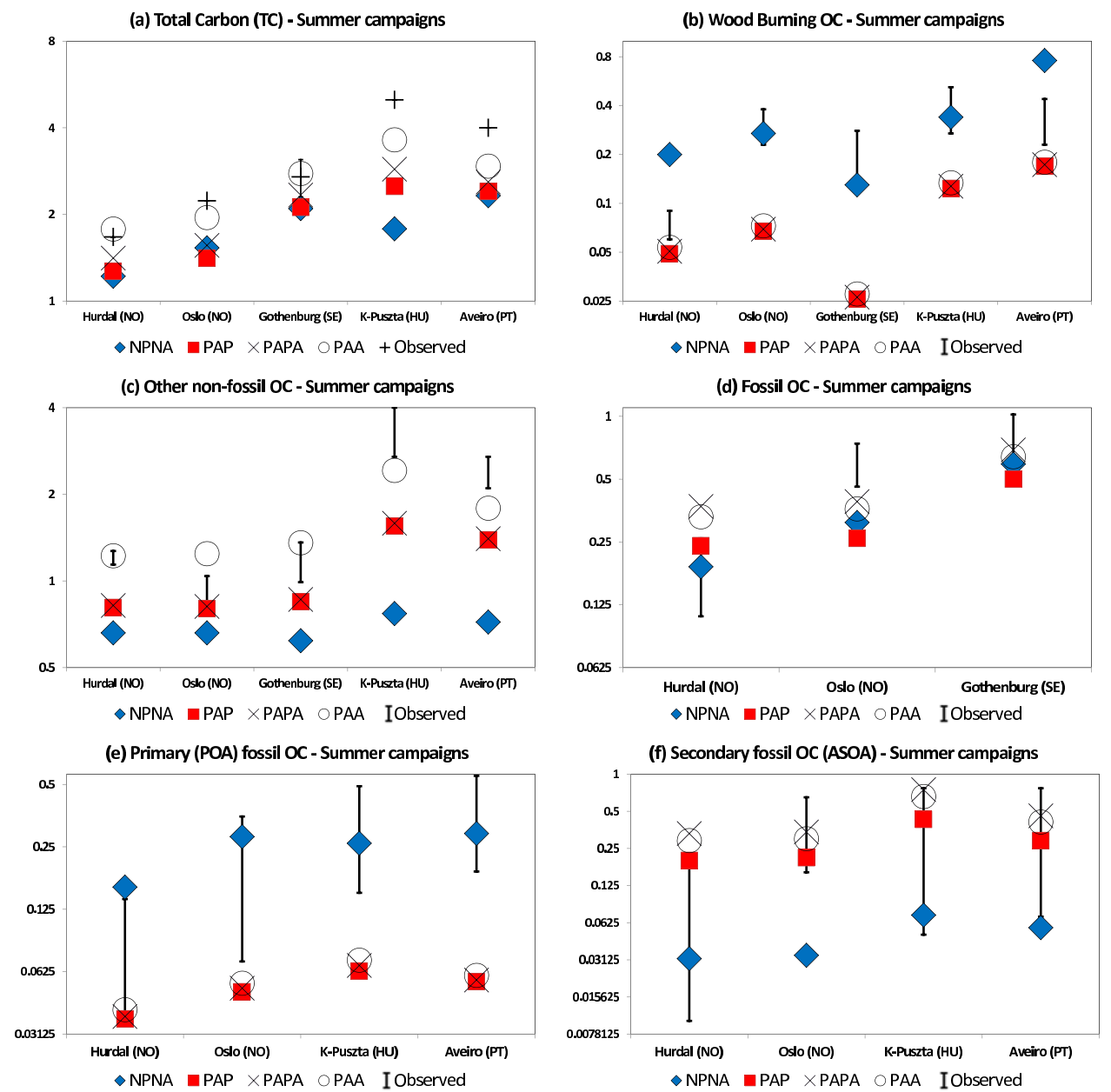

Fig. 10. Source apportionment studies during summer periods (May-October). Comparison of model results to observation-derived values for different source categories of organic carbon and for total carbon (units $\mu \mathrm{g}(\mathrm{C}) \mathrm{m}^{-3}$ ). The observed values for the different source categories are based on a statistical approach (Latin-hypercube sampling) and given as 10-90th percentiles (SORGA and Göte campaigns: NO and SE stations) or 5-95th percentiles (CARBOSOL campaign: HU and PT stations). Further details, see text and Table S5.

underestimates $\mathrm{OC}_{\mathrm{wood}}$ in Gothenburg but does a good job for $\mathrm{OC}_{\mathrm{Onf}}$. Fossil $\mathrm{OC}$ and $\mathrm{EC}$ are underestimated at the urban station (as expected). The $\mathrm{EC}_{\text {wood }}$ is well modelled in contrast to the underestimation of $\mathrm{OC}_{\mathrm{wood}}$. The model results for the rural background station Råö, outside Gothenburg, are fairly good for TC (underestimated by ca 20\%) but the individual components are not so well reproduced, with large underestimations of $\mathrm{OC}_{\mathrm{wood}}$ and $\mathrm{OC}_{\mathrm{f}}$ and a too high estimate of $\mathrm{OC}_{\text {onf }}$.

The model results for the Norwegian SORGA campaign are very different and do not agree well with the winter data from this campaign. Both the wood burning and other nonfossil contributions are greatly overestimated. At the rural station Hurdal the total fossil OC contribution is in good agreement with the S-A analysis but the fraction of ASOA is greatly underestimated and the primary $\mathrm{OA}$ is overestimated. TC is strongly overestimated even for Oslo where an under- estimation would be expected with the coarse model resolution used.

The combined results from the SORGA and Göte campaigns point to a too high contribution from background OC in the model during winter. Of the four sites only Gothenburg has $\mathrm{OC}_{\text {onf }}$ concentrations close to or above the model background OC of $0.5 \mu \mathrm{g}(\mathrm{C}) \mathrm{m}^{-3}$. This is consistent with the results discussed in Sect. 5.4.

Wintertime (November-April) $\mathrm{OC}_{\text {wood }}$ at the CARBOSOL sites are underestimated by more than a factor of ten. Similar results were found by Simpson et al. (2007). That study showed that much higher emissions from woodburning were required in order to explain the observed levoglucosan levels, and accounting for this would also explain almost all of the discrepancy between modelled and observed TC. 
For Aveiro fossil OC is also severely underestimated compared to the measurements, much more so than in Simpson et al. 2007, presumably as a result of the different emission inventories in use. Results for K-Puszta are only marginally better, fossil OC is underestimated by a factor of five.

\subsection{Residential wood burning emissions}

Residential burning of biomass fuels (e.g. wood) is a major source of organic aerosol in Europe but the emission estimates are, along with those of BVOC, among the most uncertain. The comparison of model results to both long-term measurements of $\mathrm{OC}$ and source apportionment data indicate that the wood burning emissions may be underestimated in large parts of Europe in the emission inventory used in this study.

The model results are in general in much poorer agreement with observations for winter than for summer periods. Although the model resolution used in this study cannot capture very local phenomena, such as nearby residential wood burning, under-prediction of wintertime TC seems rather common when multiple sites are studied. Local dispersion in winter conditions (e.g. inversions) is also difficult to treat accurately in a regional scale model, but, as noted in Sect. 5.4, model results for pollutants such as $\mathrm{NO}_{2}$ are usually much better. As discussed also in Simpson et al. (2007), Genberg et al. (2011) and Gilardoni et al. (2011), the main reason for this winter problem is likely underestimation of emissions from residential wood combustion in some areas of Europe.

The more detailed results from the Scandinavian S-A studies (Sect. 5.5) also indicate that the wood burning emissions in the Gothenburg region in Sweden were severely underestimated during winter while the opposite was found in the Oslo region in Norway, where the emissions used in the model seem to be heavily overestimated during the winter period. A recent study by Genberg et al. (2011) has also shown much larger contributions of wood burning to OC in southern Sweden than model estimates using the same emission inventory as in the present study.

To investigate this further we compared the activity data and related PM and OC emissions from residential wood combustion in Norway and Sweden. Total wood use in Sweden is about $60 \%$ higher than in Norway, however, the estimated OC emission for Sweden for this sector is a factor of 14 lower than for Norway!

The difference can be traced back to the reported PM emissions by country for residential combustion. Denier van der Gon et al. (2009) applied specific fractions for EC and OC to $\mathrm{PM}$ emissions derived from the IIASA GAINS model (Kupiainen and Klimont, 2004, 2007). The GAINS model determines PM emissions bottom-up but then goes through specific country consultation sessions to optimise the use of national data. In this case the Norwegian $\mathrm{PM}_{2.5}$ emissions according to GAINS is about a factor of ten higher than the Swedish $\mathrm{PM}_{2.5}$ emission for the same source sector. Since
EC and OC were estimated as a fraction of PM, also the EC and OC emissions differ dramatically. This discrepancy explains why the comparison between measured and modelled concentrations can be dramatically different for two neighbouring countries.

In a follow-up study (Denier van der Gon et al., 2012), we will present results from an alternative EC and OC emission inventory for residential combustion by using consistent direct emission factors per unit of activity for all European countries.

\subsection{Comparison to aerosol mass spectrometry (AMS) measurements}

Model calculated OM concentrations are compared to AMS measurements from Payerne in Switzerland for the period 31 May to 3 July, 2006. These measurements were part of the EMEP intensive measurement period in 2006 and were performed by PSI (Lanz et al., 2010). Examples of results are presented in Fig. 12 and Table 6. All model versions underestimate the observed OM-concentrations. Differences are large between the different versions. When primary emissions are treated as nonvolatile and no aging reactions are included for the SOA (NPNA) the model $\mathrm{OM}_{\mathrm{PM}_{2.5}}$ is a factor of three lower than the observed OM-concentrations. Model results improve when aging reactions are included for both the primary emissions and SOA. With the PAA version the model concentration is on the average $27 \%$ lower than the AMS measurements.

Since the biogenic SOA is very important during summer, and the BVOC-emissions are highly uncertain, a sensitivity test was performed, with the PAA model version, with three times larger emissions of terpene and isoprene. This gives an indication of the level of uncertainty that the BVOCemissions introduce in the model results. The higher BVOCemissions lead to higher $\mathrm{OM}_{\mathrm{PM}_{2.5}}$ concentrations at Payerne and for the first half of the measurement campaign the agreement with AMS measurements is much better than with standard emissions. However, for the last week of the campaign the model now overshoots the observed concentrations dramatically and for the period as a whole there is no clear improvement when BVOC emissions are tripled.

A detailed modelling study covering the Payerne AMS measurements has been performed by Aksoyoglu et al. (2011). They used the CAMx model with 2-way nesting down to a $3 \times 3 \mathrm{~km}^{2}$ grid resolution for Switzerland. The model included ASOA formation from aromatics and BSOA from isoprene, terpenes and sesquiterpenes; oligomerisation reactions were also included in a simplified way. POA emissions were treated as non-volatile. In spite of the coarser model resolution, the EMEP PAA model gives OM results of similar quality (or even slightly better) than the CAMx model results in Aksoyoglu et al. (2011) for the June measurements at Payerne (see Table 6). 

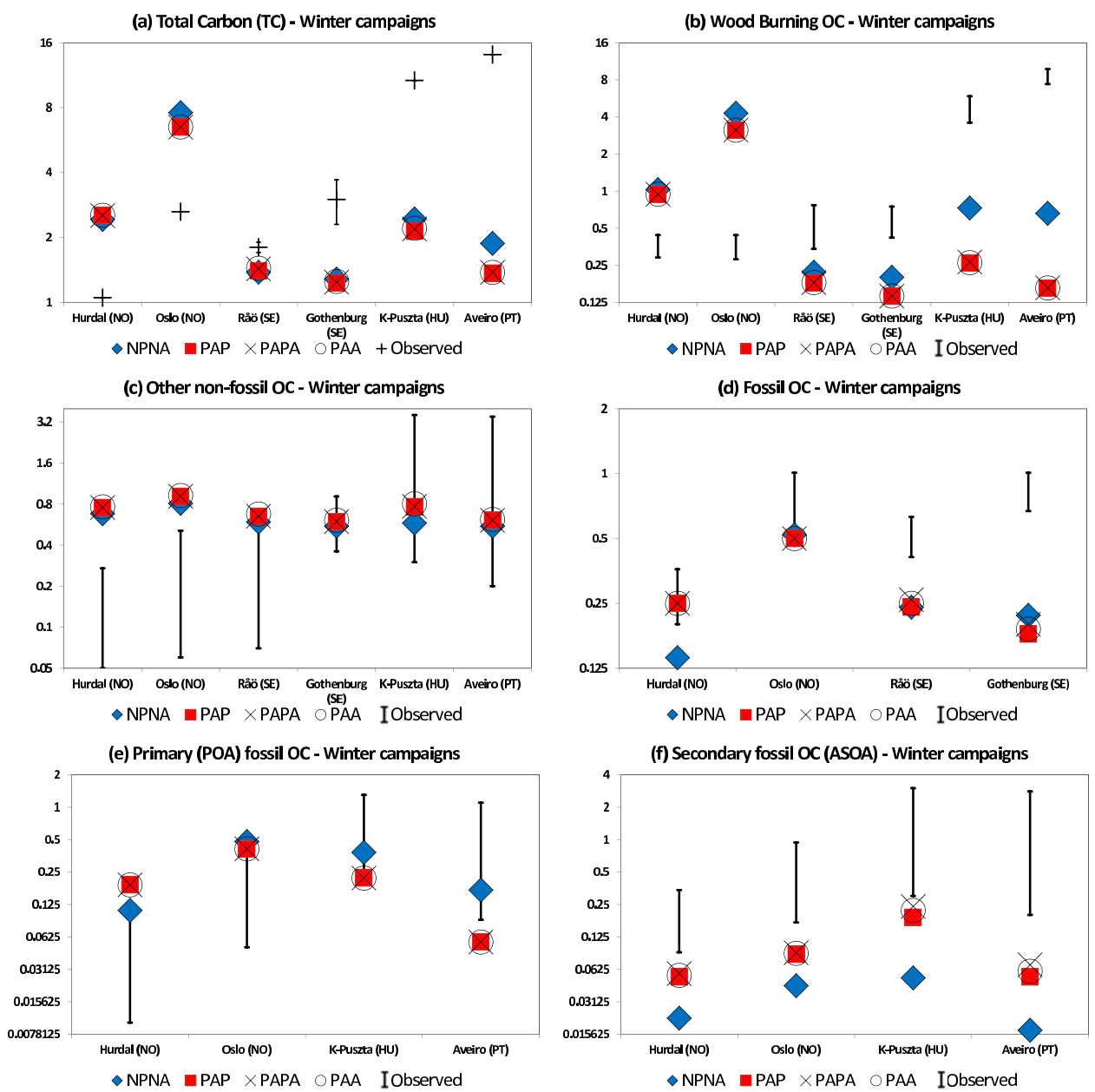

Fig. 11. Source apportionment studies during winter periods (November-April). Comparison of model results to observation-derived values for different source categories of organic carbon and for total carbon (units $\mu \mathrm{g}(\mathrm{C}) \mathrm{m}^{-3}$ ). The observed values for the different source categories are based on a statistical approach (Latin-hypercube sampling) and given as 10-90th percentiles (SORGA and Göte campaigns: NO and SE stations) or 5-95th percentiles (CARBOSOL campaign: HU and PT stations). Further details, see text and Table S6.

Factor analysis of the AMS-data indicate that about $6 \%$ of the organic aerosol is primary (fresh) OA (Lanz et al., 2010; Aksoyoglu et al., 2011). When primary emissions are treated as non-volatile (traditional approach) the POA-fraction is overestimated (the NPNA model gives $23 \%$ POA, similar to the $26 \%$ calculated by Aksoyoglu et al., 2011). The model versions that treat the primary emissions within the VBSsystem (PAP, PAPA, PAA) seem to give more realistic fractions of fresh POA at Payerne during summer (ca. 3-4\%). These results support the idea that models (and emission inventories) need to take into account the volatility distribution and atmospheric aging of primary OA for a realistic description of the properties of the organic aerosol.

\subsection{Comparison to other modelling studies}

The model results in this study show some marked differences to the earlier EMEP EC/OC model (Simpson et al.,
2007) (or those of Bessagnet et al., 2008). The geographical distribution of OC over Europe and the relative contributions from different sources to the organic aerosol differ significantly between the new model and the results in Simpson et al. (2007).

An obvious difference between the two studies is that the new model includes emissions from vegetation fires, which the old model did not. This explains some of the changes in the modelled OC distribution (new areas with relatively high OC concentrations in eastern Europe) but there are several other important differences as well.

The most striking differences in the geographical distribution of modeled total OC is that the (Kam-2X) results in Simpson et al. (2007) show a large area with high OC concentrations in northern Europe and another highconcentration region in central Europe. In the present study we find none of these to have particularly high yearly average OC concentrations. 
Table 6. Organic aerosol in fine particles at Payerne (Switzerland) for the period 31 May to 3 July 2006. Comparison of EMEP PCM model results to aerosol mass spectrometry measurements and a high-resolution model study (Lanz et al., 2010; Aksoyoglu et al., 2011). Statistics for 665 hourly measurements for the Organic Mass and monthly average Primary Organic Aerosol and Other (oxidised) Organic Aerosol fractions.

\begin{tabular}{lrrrrrrr}
\hline & Observed & NPNA & PAP & PAPA & PAA & PAA(BVOCx3) & $\begin{array}{r}\text { Aksoyoglu } \\
\text { et al. }(2011)\end{array}$ \\
\hline Organic Mass $\left(\mu \mathrm{g} \mathrm{m}^{-3}\right)$ & 6.1 & 2.0 & 2.6 & 3.4 & 4.5 & 7.7 & 4.5 \\
Mean Fractional Bias & & $-86 \%$ & $-68 \%$ & $-47 \%$ & $-25 \%$ & $+20 \%$ & $-35 \%$ \\
Mean Fractional Error & & $87 \%$ & $70 \%$ & $52 \%$ & $38 \%$ & $39 \%$ & $50 \%$ \\
Correlation coeff. (r) & & 0.58 & 0.60 & 0.58 & 0.60 & 0.58 & $26 \%$ \\
POA-fraction & $6 \%$ & $23 \%$ & $4.4 \%$ & $3.7 \%$ & $3.0 \%$ & $2.1 \%$ & $74 \%$ \\
Other OA-fraction & $94 \%$ & $77 \%$ & $96 \%$ & $96 \%$ & $97 \%$ & $98 \%$ & $74 \%$ \\
\hline
\end{tabular}

Notes: the Observed Fresh POA and Other OA-fractions are based on factor analysis of AMS-data and are taken from Aksoyoglu et al. (2011). The POA fraction from Aksoyoglu et al. is interpreted as Fresh POA (including both fossil and wood burning sources) and the Other OA-fraction ("SOA" in Aksoyoglu et al.) includes all other OA, i.e., traditional SOA as well as SOA formed from aging of S/IVOC emissions from different sources.

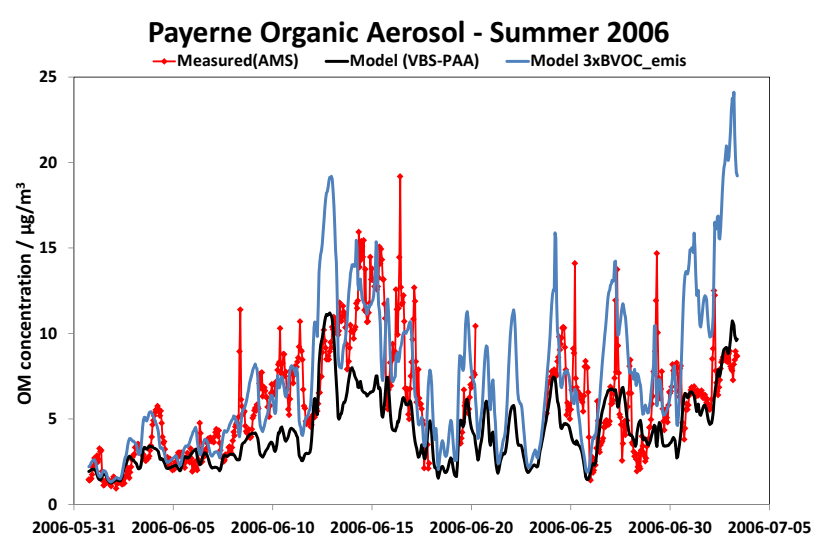

Fig. 12. Total organic mass in fine particles at Payerne, Switzerland (AMS measurements (red curve), $\mathrm{OM}$ in $\mathrm{PM}_{1}$ and model calculated $\mathrm{OM}$ in $\mathrm{PM}_{2.5}$ with the PAA model version (black curve: standard BVOC emissions, blue curve: sensitivity test with BVOC emissions tripled)). Unit: $\mu \mathrm{g} \mathrm{m}^{-3}$.

One reason for the much lower estimate of the BSOA in this study may be the new BVOC emission estimates used here. It is also possible that the use of low "effective" vapor pressures for the BSOA components in the Kam-2X model used by Simpson et al. (2007) led to much greater partitioning to the particle phase. Indeed, that study highlighted that the use of different vapour pressure assumptions (the Kam-2 versus Kam-2X schemes) dramatically alters SOA formation.

Another big difference between the two studies is that the calculated $\mathrm{ASOA}_{\mathrm{f}}^{\mathrm{V}}$ contribution to $\mathrm{OM}_{\mathrm{PM}_{2.5}}$ is much larger with the new model, especially if aging reactions are included for the semi-volatile ASOA components in the VBSscheme (PAPA and PAA models). The reason for the small $\mathrm{ASOA}_{\mathrm{f}}^{\mathrm{V}}$-contribution in Simpson et al. (2007) (and other studies) is likely the usage of older (lower) estimates of SOA formation from oxidation of aromatic compounds in that study; the yields from such compounds have been revised dramatically upwards in recent years ( $\mathrm{Ng}$ et al., 2007a; Hildebrandt et al., 2009; Hallquist et al., 2009).

Fountoukis et al. (2011) recently used the PMCAMx-2008 model for a study of $\mathrm{PM}_{1}$ in Europe during the EUCAARI campaign in May 2008. PMCAMx-2008 includes an organic aerosol scheme, which is very similar to the PAPA model version of this study, and it is interesting to compare the results of this study to Fountoukis et al. (2011). Since the present study does not include 2008, a direct comparison of the results is not possible but we have extracted model results for the six May months of 2002-2007 (see Figs. S12, S13) and compare these to the 2008 results in Fountoukis et al. (2011).

For most parts of Europe the calculated total organic aerosol in fine particles is lower in the study by Fountoukis et al. (2011) than the corresponding results (for 2002-2007) with the EMEP PAPA model. This is especially clear over southern Europe and the Mediterranean and Black Seas. We also get higher concentrations in western Russia, Belarus and Ukraine (possibly due to some periods with high emissions from vegetation fires in this region during the period 2002 2007).

Fountoukis et al. (2011) calculate higher OA concentrations over England, the English Channel, the North Sea and the Benelux countries, the south-eastern Baltic Sea, as well as over some urban hotspots, especially St. Petersburg. This seems mostly to be due to much higher "Fresh POA" concentrations in these regions in the PMCAMx-2008 model compared to the present study. The fresh POA in PMCAMx includes oceanic emissions (from sea spray) and this source of $\mathrm{OA}$ is not explicitly included in the present version of the EMEP model, which may explain some of the differences in and near sea areas. For many high-emission hotspots it seems that the PMCAMx emissions are much less dispersed (and/or evaporated) than in the EMEP model, which may indicate that some differences are due to model resolution and possibly dispersion issues. 


\section{Discussion}

The focus of this paper has been on illustrating the range of model values which can be obtained using different VBS assumptions, comparing these with long-term measurement data. It is clear that as well as uncertainties in the VBS assumptions explicitly explored here, there are a large number of factors which influence model-measurement comparisons. We cannot cover all aspects of such uncertanties, but briefly consider some of the major problems associated with SOA models.

A general issue is the reliability of the yield data and the aging schemes used in VBS studies. As noted in Sect. 5, very high concentrations of ASOA are sometimes produced by VBS schemes which allow aging. Indeed, the parameters given in Table 4 (based on Tsimpidi et al. 2010, and references therein) allow for yields exceeding $100 \%$ in high $\mathrm{OH}$ (high aging) low NOx conditions, and this accounts for some of the very high OM levels found in the PAPA and PAA schemes, e.g. over the Mediteranean in summertime. These maximum yields are far higher than seen in smog-chamber experiments (e.g. Ng et al., 2007a,b). Although there are theoretical arguments and measurements supporting high yields (or prevalence of low volatility OA, as opposed to semivolatile OA generated in smog-chambers) (Donahue et al., 2005; Ng et al., 2010), the high yield found in VBS schemes are clearly an extrapolation from smog-chamber to ambientatmosphere, combined with an aging effect which continually creates OA of lower and lower volatilty. This "zombie" effect (all the high $C^{*}$ bins marching towards low volatility, Donahue's terminology) is certainly unrealistic in the type of model used here. The 2-D VBS framework (Jimenez et al., 2009), which allows for fragmentation, was recently introduced and helps to avoid these problems. Recent experimental work by e.g. Henry and Donahue (2012) suggests photolysis as one contributor to increasing volatility, but also indicates that the behaviour is complex.

Another issue is that in the VBS models used in this study, indeed in gas/particle SOA models in general, the partitioning is assumed to be rapid. This means that SOA may evaporate quickly upon dilution. Recent work by Vaden et al. (2011) has shown that real SOA evaporation is much slower than expected from simple models that assume that the particles are liquid droplets.

Emissions are of course a major challenge, especially for the two major sources, BVOC and residential wood combustion emissions. With regard to BVOC, then there are simply too few data with which we can evaluate the model. The EMEP network (Tørseth et al., 2012) has some isoprene data from the 1990s onwards, but this compound (and indeed many of the BVOC we are interested in) has a very short lifetime, and strong gradients near the surface that we cannot capture with the EMEP model.

Unfortunately even where measurements exist, it seems to be a difficult task to interpret them for our purposes.
For example, Davison et al. (2009) measured isoprene and monoterpenes for Italian Macchia ecosystems. They found monoterpene emissions from flux measurements to be in reasonable agreement with estimates made from leaf-level data, but the isoprene basal emissions rates were quite different. They believed that unrepresentative sampling in the measurement area might explain some of this, but they also showed how different studies at the same site can produce quite different emissions estimates. Similarly, Seco et al. (2011) measured isoprene and terpenes near Barcelona, but the measurements were taken at $3 \mathrm{~m}$ height in a forest gap.

Datasets for monoterpenes in Europe are even fewer than for isoprene, and again often located close to forest-canopies and thus difficult to interpret. As stressed also in Simpson et al. (2007), this lack of data on European BVOC fluxes is a major impediment to any attempt to model SOA in a realistic way.

It should also be noted that the emission inventory used in this work has only small contributions from cooking emissions. Although cooking emissions were established many years ago as major sources of $\mathrm{OA}$ in Northern America (e.g. Schauer et al., 1996, 2002; Ham and Kleeman, 2011), it has been assumed in most European inventories that this is not a major source. The reasons include a lower consumption of fried food in Europe, and less outdoor cooking in general.

However, Mohr et al. (2012) recently found that primary OA in Barcelona contained almost $60 \%$ of non-fossil carbon from cooking sources during March 2009. On the other hand, Barcelona is a very large (population 5 million) city with very strong urban impacts on air quality, and is not necessarily typical of the rest of the Europe. Szidat et al. (2009) found that both the water soluble and water-insoluble (WINSOC) fractions of organic carbon sampled in and around Gothenburg in Sweden showed similar fractions of modern carbon. As cooking emissions should be associated primarily with the WINSOC fraction, this similarity was interpreted to suggest that cooking was not of major importance even in the centre of this moderately sized (500000 inhabitants) city. Thus, the question of the importance of cooking emissions in the European inventory is still open, but obviously one that warrants urgent attention. The addition of cooking emissions to the inventory would of course raise urban organic aerosol levels, and also affect the interpretation of sourceapportionment data based upon ${ }^{14} \mathrm{C}$ measurements.

A certain underestimation of $\mathrm{OC}_{\mathrm{PM}_{10}}$ (and $\mathrm{TC}_{\mathrm{PM}_{10}}$ ) is to be expected also due to missing emissions of primary biological particles in the model. These may be an important fraction of $\mathrm{OC}_{\mathrm{PM}_{10}}$ (Winiwarter et al., 2009; Yttri et al., 2011; Heald and Spracklen, 2009). Local sources are likely to have a relatively large impact on the primary biological particles, which complicates the comparison of the regional scale model results to $\mathrm{OC}_{\mathrm{PM}_{10}}$ measurements.

Another important and difficult issue is the representativity of a measurement for a larger scale. Organic aerosol has many different types of sources, both anthropogenic and 
biological. Measurement stations that are considered regionally representative for "traditional" air pollutants of mostly anthropogenic origin (e.g. ozone, $\mathrm{NO}_{\mathrm{x}}, \mathrm{SO}_{\mathrm{x}}$ ) may be influenced by non-urban but still relatively local sources of organic aerosol, such as (rural) residential wood burning, open fires and primary biological particles.

The measurements themselves may also be subject to substantial uncertainties. A worrying example is that co-located ${ }^{14} \mathrm{C}$ measurements in Mexico City by two different groups showed large discrepancies, as pointed out by Aiken et al. (2010), and discussed in detail in Hodzic et al. (2010b). The size of the discrepancy was surprisingly large, with average non-fossil fractions of 0.54 in the US PM$_{1}$ filters versus 0.34 for the Swiss $\mathrm{PM}_{10}$ filters. There were however just four filters that could be compared, so we are reluctant to draw too many conclusions from this case. In Europe, a number of comparisons suggest that uncertainties in ${ }^{14} \mathrm{C}$ analysis between different laboratories (S. Szidat, personal communication, 2012) are far smaller than this.

\section{Conclusions}

The EMEP MSC-W chemical transport model for Europe has been extended with a new scheme for treatment of organic aerosol by the volatility basis set (VBS) approach. The VBS scheme requires a number of assumptions concerning the volatilty and aging of semi-volatile and intermediate volatility compounds, and results are often quite sensitive to these choices. In this work we explore the sensitivity of the results to the VBS parameters, and compare long-term model simulations for the years 2002-2007 with measurements. The main conclusions from these simulations and comparisons to observations are as follows:

- During summertime BSOA, ASOA and vegetation fires are all important contributors to the modelled organic aerosol concentrations in Europe. The relative importance of the sources depends on the assumptions about aging of the semi-volatile SOA species.

- ASOA is only important if aging reactions are included for the anthropogenic S/IVOC species. BSOA gives fairly significant contributions to the organic aerosol even when no aging is included but much more so with aging reactions. However, some of the yields found when allowing for aging of ASOA and BSOA species are very high, far beyond those seen in smog-chambers. Although multi-generational aging may indeed increase yields, more complex schemes (e.g. 2-D VBS, see below) would likely give quite different results. The realism of these processes in the real atmosphere is still to be determined.

- For summer periods, major model uncertainties are related to the assumed BVOC emissions. These emissions are highly uncertain, but there are too few observational data on either emission rates, or ambient concentrations, so model evaluation is extremely difficult. Clearly, more data are needed on BVOC emission rates in Europe before summertime SOA formation can be evaluated properly in chemical transport models.

- Vegetation fire emissions contributed significantly to average concentrations of $\mathrm{OM}_{\mathrm{PM}_{2.5}}$ in large parts of Europe, especially the eastern part of Europe and the western part of the Iberian peninsula.

- Wintertime OA has important contributions from residential wood burning, as well as fossil sources. However, the model/emission combinations tested in this study are not able to reproduce winter time levels of particulate carbonaceous matter (PCM) in Europe. The wintertime problems found for PCM are far worse than those found for other pollutants (e.g. $\left.\mathrm{NO}_{2}\right)$ in the EMEP model, and may to a large extent be due to known problems with the emission estimates for residential woodburning. There is clearly a strong need to evaluate and improve the emissions inventories for residential wood combustion.

- The results discussed above suggest that the addition of aging reactions significantly improves summertime results at most sites, although has little (or even negative) consequences in wintertime. These are results are consistent with SOA formation being very important in summer, and primary emissons being more important in winter.

- Since there are large sources of non-fossil OM at all times of year (BSOA, residential wood combustion, vegetation fires, background $\mathrm{OM}$ ) the total $\mathrm{OC}$ in the model is dominated by modern carbon.

- The results shown here indicate that it is very important to determine the volatility distribution of primary OA emissions, and the atmospheric reactivity of the POA.

- The assumption in most VBS studies that there exists a class of S/IVOC which is not accounted for in current $\mathrm{PM}$ and/or VOC inventories needs to be investigated. Assumptions concerning this derive entirely from a very limited amount of data from North America, but organic aerosol from these sources can contribute significantly to particulate carbonaceous matter in Europe.

The VBS-framework was introduced in North America as a useful approach to capturing the complexity of organic aerosol formation in a managable algorithm. The approach is well suited for chemical transport models. However, given the limitations of any OA-modelling scheme, including uncertainties surrounding emissions, formation, and other modelling issues, there is of course a danger that results are improved for the wrong reasons. As one example, an increase 
in BVOC emission rates might give comparable effects to an increase in aerosol yields or aging rates. Another example would be that the high ASOA yields predicted by VBS might be masking problems in POA emissions. Untangling these effects is a real challenge.

Thus, the intention of this paper has not been to nominate a "best" model setup; we believe that this is not yet possible. However, the sensitivity results discussed here illustrate the general capabilities and uncertainties of current modelling efforts, and give guidance as to where to focus future efforts.

Future plans involve further work investigating alternative (bottom-up) emission estimates for residential wood burning in Europe, and further detailed comparison of the model with newly available filter and AMS data. Major data-sets involve the EMEP intensive of 2008-2009 and data from the EU EUSAAR (e.g. Laj et al., 2009) and EUCAARI projects (Kulmala et al., 2011). Further work is also needed to better estimate background/boundary concentrations of organic aerosol (due to oceanic (sea-spray) and long-range transport sources) and primary biological OA.

In addition, the use of more complex representations of $\mathrm{OA}$ needs to be considered. For example the 2-D VBS scheme (Jimenez et al., 2009; Donahue et al., 2011) offers more realism in the oxidation and fragmentation pathways. It is an open question at this stage, especially considering the uncertainty in emissions, whether such schemes will improve our ability to simulate ambient OA concentrations.

\section{Supplementary material related to this article is available online at: http://www.atmos-chem-phys.net/12/ 8499/2012/acp-12-8499-2012-supplement.pdf.}

Acknowledgements. We thank two anonymous referees for valuable comments that helped to improve this manuscript. This work was funded by the Swedish Clean Air Research Programme (SCARP), the EU FP6 EUCAARI project (No. 34684), the Norwegian SORGA project, as well as by EMEP under UNECE.

Edited by: M. Beekmann

\section{References}

Aas, W., Tsyro, S., Bieber, E., Bergström, R., Ceburnis, D., Ellermann, T., Fagerli, H., Frölich, M., Gehrig, R., Makkonen, U., Nemitz, E., Otjes, R., Perez, N., Perrino, C., Prévôt, A. S. H., Putaud, J.-P., Simpson, D., Spindler, G., Vana, M., and Yttri, K. E.: Lessons learnt from the first EMEP intensive measurement periods, Atmos. Chem. Phys., 12, 8073-8094, doi:10.5194/acp12-8073-2012, 2012.

Aiken, A. C., Decarlo, P. F., Kroll, J. H., Worsnop, D. R., Huffman, J. A., Docherty, K. S., Ulbrich, I. M., Mohr, C., Kimmel, J. R., Sueper, D., Sun, Y., Zhang, Q., Trimborn, A., Northway,
M., Ziemann, P. J., Canagaratna, M. R., Onasch, T. B., Alfarra, M. R., Prevot, A. S. H., Dommen, J., Duplissy, J., Metzger, A., Baltensperger, U., and Jimenez, J. L.: O/C and OM/OC ratios of primary, secondary, and ambient organic aerosols with highresolution time-of-flight aerosol mass spectrometry, Environ. Sci. Technol., 42, 4478-4485, doi:10.1021/es703009q, 2008.

Aiken, A. C., de Foy, B., Wiedinmyer, C., DeCarlo, P. F., Ulbrich, I. M., Wehrli, M. N., Szidat, S., Prevot, A. S. H., Noda, J., Wacker, L., Volkamer, R., Fortner, E., Wang, J., Laskin, A., Shutthanandan, V., Zheng, J., Zhang, R., Paredes-Miranda, G., Arnott, W. P., Molina, L. T., Sosa, G., Querol, X., and Jimenez, J. L.: Mexico city aerosol analysis during MILAGRO using high resolution aerosol mass spectrometry at the urban supersite (T0) Part 2: Analysis of the biomass burning contribution and the non-fossil carbon fraction, Atmos. Chem. Phys., 10, 5315-5341, doi:10.5194/acp-10-5315-2010, 2010.

Aksoyoglu, S., Keller, J., Barmpadimos, I., Oderbolz, D., Lanz, V. A., Prévôt, A. S. H., and Baltensperger, U.: Aerosol modelling in Europe with a focus on Switzerland during summer and winter episodes, Atmos. Chem. Phys., 11, 7355-7373, doi:10.5194/acp11-7355-2011, 2011.

Andersson-Sköld, Y. and Simpson, D.: Comparison of the chemical schemes of the EMEP MSC-W and the IVL photochemical trajectory models, Atmos. Environ., 33, 1111-1129, 1999.

Andersson-Sköld, Y. and Simpson, D.: Secondary organic aerosol formation in Northern Europe: a model study, J. Geophys. Res., 106, 7357-7374, 2001.

Benedictow, A.: Documentation and verification of the 1999 PARLAM-PS meteorological fields used as input for Eulerian EMEP model, Tech. rep., The Norwegian Meteorological Institute, Oslo, Norway, research Note no. 111. (Reports also available for 1980, 1985, 1995, 1999, 2000 and 2001, see www.emep. int), 2003.

Berge, E. and Jakobsen, H. A.: A regional scale multi-layer model for the calculation of long-term transport and deposition of air pollution in Europe, Tellus, 50, 205-223, 1998.

Bessagnet, B., Menut, L., Curci, G., Hodzic, A., Guillaume, B., Liousse, C., Moukhtar, S., Pun, B., Seigneur, C., and Schulz, M.: Regional modeling of carbonaceous aerosols over Europe-focus on secondary organic aerosols, J. Atmos. Chem., 61, 175-202, doi:10.1007/s10874-009-9129-2, 2008.

Bessagnet, B., Seigneur, C., and Menut, L.: Impact of dry deposition of semi-volatile organic compounds on secondary organic aerosols, Atmos. Environ., 44, 1781-1787, doi:10.1016/j.atmosenv.2010.01.027, 2010.

Bjørge, D. and Skålin, R.: PARLAM the parallel HIRLAM version at DNMI, Research Report 27, The Norwegian Meteorological Institute, Oslo, Norway, 1995.

Canagaratna, M. R., Jayne, J. T., Jimenez, J. L., Allan, J. D., Alfarra, M. R., Zhang, Q., Onasch, T., Drewnick, F., Coe, H., Middlebrook, A., Delia, A., Williams, L. R., Trimborn, A. M., Northway, M. J., DeCarlo, P. F., Kolb, C. E. Davidovits, P., and Worsnop, D. R.: Chemical and microphysical characterization of ambient aerosols with the aerosol mass spectrometer, Mass Spectrom. Rev., 26, 185-222, 2007.

Chhabra, P. S., Flagan, R. C., and Seinfeld, J. H.: Elemental analysis of chamber organic aerosol using an aerodyne high-resolution aerosol mass spectrometer, Atmos. Chem. Phys., 10, 4111-4131, doi:10.5194/acp-10-4111-2010, 2010. 
Cavalli, F., Facchini, M. C., Decesari, S., Mircea, M., Emblico, L., Fuzzi, S., Ceburnis, D., Yoon, Y. J., O’Dowd, C. D., Putaud, J. P., and Dell'Acqua, A.: Advances in characterization of size-resolved organic matter in marine aerosol over the North Atlantic, J. Geophys. Res., 109, D24215, doi:10.1029/2004JD005137, 2004.

Cubison, M. J., Ortega, A. M., Hayes, P. L., Farmer, D. K., Day, D., Lechner, M. J., Brune, W. H., Apel, E., Diskin, G. S., Fisher, J. A., Fuelberg, H. E., Hecobian, A., Knapp, D. J., Mikoviny, T., Riemer, D., Sachse, G. W., Sessions, W., Weber, R. J., Weinheimer, A. J., Wisthaler, A., and Jimenez, J. L.: Effects of aging on organic aerosol from open biomass burning smoke in aircraft and laboratory studies, Atmos. Chem. Phys., 11, 12049-12064, doi:10.5194/acp-11-12049-2011, 2011.

Davison, B., Taipale, R., Langford, B., Misztal, P., Fares, S., Matteucci, G., Loreto, F., Cape, J. N., Rinne, J., and Hewitt, C. N.: Concentrations and fluxes of biogenic volatile organic compounds above a Mediterranean macchia ecosystem in western Italy, Biogeosciences, 6, 1655-1670, doi:10.5194/bg-6-16552009, 2009.

Denier van der Gon, H., Visschedijk, A., Droge, R., Mulder, M., Johansson, C., and Klimont, Z.: A high resolution emission inventory of particulate elemental carbon and organic carbon for Europe in 2005, paper presented at 7th International Conference on Air Quality - Science and Application (Air Quality 2009), Istanbul, 24-27 March 2009, 2009.

Denier van der Gon, H., Visschedijk, A., Pandis, S., Fountoukis, C., Bergström, R., Simpson, D., and Johansson, C.: Particulate emissions from residential wood combustion in Europe - revised estimates and an evaluation, in preparation, 2012.

Donahue, N., Hartz, K., Chuong, B., Presto, A., Stanier, C., Rosenhørn, T., Robinson, A., and Pandis, S.: Critical factors determining the variation in SOA yields from terpene ozonolysis: a combined experimental and computational study, Faraday Discuss., 130, 295-309, doi:10.1039/b417369d, 2005.

Donahue, N., Robinson, A., Stanier, C., and Pandis, S.: Coupled Partitioning, Dilution, and Chemical Aging of Semivolatile Organics, Environ. Sci. Technol., 40, 2635-2643, 2006.

Donahue, N. M., Robinson, A. L., and Pandis, S. N.: Atmospheric organic particulate matter: From smoke to secondary organic aerosol, Atmos. Environ., 43, 94-106, doi:10.1016/j.atmosenv.2008.09.055, 2009.

Donahue, N. M., Epstein, S. A., Pandis, S. N., and Robinson, A. L.: A two-dimensional volatility basis set: 1. organic-aerosol mixing thermodynamics, Atmos. Chem. Phys., 11, 3303-3318, doi:10.5194/acp-11-3303-2011, 2011.

Duhl, T. R., Helmig, D., and Guenther, A.: Sesquiterpene emissions from vegetation: a review, Biogeosciences, 5, 761-777, doi:10.5194/bg-5-761-2008, 2008

Dzepina, K., Volkamer, R. M., Madronich, S., Tulet, P., Ulbrich, I. M., Zhang, Q., Cappa, C. D., Ziemann, P. J., and Jimenez, J. L.: Evaluation of recently-proposed secondary organic aerosol models for a case study in Mexico City, Atmos. Chem. Phys., 9, 5681-5709, doi:10.5194/acp-9-5681-2009, 2009.

El-Zanan, H. S., Zielinska, B., Mazzoleni, L. R., and Hansen, D. A.: Analytical Determination of the Aerosol Organic Mass-toOrganic Carbon Ratio, J. Air Waste Manage. Assoc., 59, 58-69, 2009.
Epstein, S. A., Riipinen, I., and Donahue, N. M.: A Semiempirical Correlation between Enthalpy of Vaporization and Saturation Concentration for Organic Aerosol, Environ. Sci. Technol., 44, 743-748, doi:10.1021/es902497z, 2010.

Fagerli, H. and Aas, W.: Trends of nitrogen in air and precipitation: Model results and observations at EMEP sites in Europe, 19802003, Environ. Pollut., 154, 448-461, 2008.

Fagerli, H., Gauss, M., Benedictow, A., Steensen, B., and Hjellbrekke, A.-G.: Acidifying and eutrophying components: validation and combined maps, in: EMEP Unified model performance for acidifying and eutrophying components and photo-oxidants in 2009. Supplementary material to EMEP Status Report 1/11, 1-54, 2011.

Farina, S. C., Adams, P. J., and Pandis, S. N.: Modeling global secondary organic aerosol formation and processing with the volatility basis set: Implications for anthropogenic secondary organic aerosol, J. Geophys. Res., 115, D09202, doi:10.1029/2009JD013046, 2010.

Fountoukis, C., Racherla, P. N., Denier van der Gon, H. A. C., Polymeneas, P., Charalampidis, P. E., Pilinis, C., Wiedensohler, A., Dall'Osto, M., O'Dowd, C., and Pandis, S. N.: Evaluation of a three-dimensional chemical transport model (PMCAMx) in the European domain during the EUCAARI May 2008 campaign, Atmos. Chem. Phys., 11, 10331-10347, doi:10.5194/acp11-10331-2011, 2011.

Gelencsér, A., May, B., Simpson, D., Sánchez-Ochoa, A., Kasper-Giebl, A., Puxbaum, H., Caseiro, A., Pio, C., and Legrand, M.: Source apportionment of $\mathrm{PM}_{2.5}$ organic aerosol over Europe: primary/secondary, natural/anthropogenic, fossil/biogenic origin, J. Geophys. Res., 112, D23S04, doi:10.1029/2006JD008094, 2007.

Genberg, J., Hyder, M., Stenström, K., Bergström, R., Simpson, D., Fors, E. O., Jönsson, J. Å., and Swietlicki, E.: Source apportionment of carbonaceous aerosol in southern Sweden, Atmos. Chem. Phys., 11, 11387-11400, doi:10.5194/acp-1111387-2011, 2011.

Giglio, L., Descloitres, J., Justice, C., and Kaufman, Y.: An enhanced contextual fire detection algorithm for MODIS Remote Sens. Environ., 87, 273-282, doi:10.1016/S00344257(03)00184-6, 2003.

Gilardoni, S., Vignati, E., Cavalli, F., Putaud, J. P., Larsen, B. R., Karl, M., Stenström, K., Genberg, J., Henne, S., and Dentener, F.: Better constraints on sources of carbonaceous aerosols using a combined ${ }^{14} \mathrm{C}$ - macro tracer analysis in a European rural background site, Atmos. Chem. Phys., 11, 5685-5700, doi:10.5194/acp-11-5685-2011, 2011.

Guenther, A., Zimmerman, P., Harley, P., Monson, R., and Fall, R.: Isoprene and monoterpene rate variability: model evaluations and sensitivity analyses, J. Geophys. Res., 98, 12609-12617, 1993.

Hallquist, M., Wenger, J. C., Baltensperger, U., Rudich, Y., Simpson, D., Claeys, M., Dommen, J., Donahue, N. M., George, C., Goldstein, A. H., Hamilton, J. F., Herrmann, H., Hoffmann, T., Iinuma, Y., Jang, M., Jenkin, M. E., Jimenez, J. L., Kiendler-Scharr, A., Maenhaut, W., McFiggans, G., Mentel, Th. F., Monod, A., Prévôt, A. S. H., Seinfeld, J. H., Surratt, J. D., Szmigielski, R., and Wildt, J.: The formation, properties and impact of secondary organic aerosol: current and emerging issues, Atmos. Chem. Phys., 9, 5155-5236, doi:10.5194/acp-9-51552009, 2009. 
Ham, W. A. and Kleeman, M. J.: Size-resolved source apportionment of carbonaceous particulate matter in urban and rural sites in central California, Atmos. Environ., 45, 3988-3995, doi:10.1016/j.atmosenv.2011.04.063, 2011.

Heald, C. L. and Spracklen, D. V.: Atmospheric budget of primary biological aerosol particles from fungal spores, Geophys. Res. Lett., 36, L09806, doi:10.1029/2009GL037493, 2009.

Heintzenberg, J.: Fine particles in the global troposphere - a review, Tellus, 41B, 149-160, 1989.

Henry, K. and Donahue, N.: Photochenical aging of $\alpha$-pinene secondary organic aerosol: effects of $\mathrm{OH}$ radical sources and photolysis, J. Phys. Chem., 116, 5932-5940, 2012.

Hildebrandt, L., Donahue, N. M., and Pandis, S. N.: High formation of secondary organic aerosol from the photo-oxidation of toluene, Atmos. Chem. Phys., 9, 2973-2986, doi:10.5194/acp-92973-2009, 2009.

Hodzic, A., Jimenez, J. L., Madronich, S., Canagaratna, M. R., DeCarlo, P. F., Kleinman, L., and Fast, J.: Modeling organic aerosols in a megacity: potential contribution of semi-volatile and intermediate volatility primary organic compounds to secondary organic aerosol formation, Atmos. Chem. Phys., 10, 5491-5514, doi:10.5194/acp-10-5491-2010, 2010a.

Hodzic, A., Jimenez, J. L., Prévôt, A. S. H., Szidat, S., Fast, J. D., and Madronich, S.: Can 3-D models explain the observed fractions of fossil and non-fossil carbon in and near Mexico City?, Atmos. Chem. Phys., 10, 10997-11016, doi:10.5194/acp10-10997-2010, 2010 b.

Jimenez, J. L., Canagaratna, M. R., Donahue, N. M., Prévôt, A. S. H., Zhang, Q., Kroll, J. H., DeCarlo, P. F., Allan, J. D., Coe, H., Ng, N. L., Aiken, A. C., Docherty, K. S., Ulbrich, I. M., Grieshop, A. P., Robinson, A. L., Duplissy, J., Smith, J. D., Wilson, K. R., Lanz, V. A., Hueglin, C., Sun, Y. L., Tian, J., Laaksonen, A., Raatikainen, T., Rautiainen, J., Vaattovaara, P., Ehn, M., Kulmala, M., Tomlinson, J. M., Collins, D. R., Cubison, M. J., Dunlea, E. J., Huffman, J. A., Onasch, T. B., Alfarra, M. R., Williams, P. I., Bower, K., Kondo, Y., Schneider, J., Drewnick, F., Borrmann, S., Weimer, S., Demerjian, K., Salcedo, D., Cottrell, L., Griffin, R., Takami, A., Miyoshi, T., Hatakeyama, S., Shimono, A., Sun, J. Y., Zhang, Y. M., Dzepina, K., Kimmel, J. R., Sueper, D., Jayne, J. T., Herndon, S. C., Trimborn, A. M., Williams, L. R., Wood, E. C., Middlebrook, A. M., Kolb, C. E., Baltensperger, U., and Worsnop, D. R.: Evolution of Organic Aerosols in the Atmosphere, Science, 326, 1525-1529, doi:10.1126/science.1180353, 2009.

Jonson, J. E., Simpson, D., Fagerli, H., and Solberg, S.: Can we explain the trends in European ozone levels?, Atmos. Chem. Phys., 6, 51-66, doi:10.5194/acp-6-51-2006, 2006.

Kanakidou, M., Seinfeld, J. H., Pandis, S. N., Barnes, I., Dentener, F. J., Facchini, M. C., Van Dingenen, R., Ervens, B., Nenes, A., Nielsen, C. J., Swietlicki, E., Putaud, J. P., Balkanski, Y., Fuzzi, S., Horth, J., Moortgat, G. K., Winterhalter, R., Myhre, C. E. L., Tsigaridis, K., Vignati, E., Stephanou, E. G., and Wilson, J.: Organic aerosol and global climate modelling: a review, Atmos. Chem. Phys., 5, 1053-1123, doi:10.5194/acp-5-1053-2005, 2005.

Karl, M., Guenther, A., Köble, R., Leip, A., and Seufert, G.: A new European plant-specific emission inventory of biogenic volatile organic compounds for use in atmospheric transport models, Biogeosciences, 6, 1059-1087, doi:10.5194/bg-6-1059-2009, 2009.
Kesik, M., Ambus, P., Baritz, R., Brüggemann, N., ButterbachBahl, K., Damm, M., Duyzer, J., Horváth, L., Kiese, R., Kitzler, B., Leip, A., Li, C., Pihlatie, M., Pilegaard, K., Seufert, S., Simpson, D., Skiba, U., Smiatek, G., Vesala, T., and ZechmeisterBoltenstern, S.: Inventories of $\mathrm{N}_{2} \mathrm{O}$ and $\mathrm{NO}$ emissions from $\mathrm{Eu}-$ ropean forest soils, Biogeosciences, 2, 353-375, doi:10.5194/bg2-353-2005, 2005.

Kleefeld, S., Hofferb, A., Krivacsy, Z., and Jennings, S.: Importance of organic and black carbon in atmospheric aerosols at Mace Head, on the West Coast of Ireland $\left(53^{\circ} 19^{\prime} \mathrm{N}, 9^{\circ} 54^{\prime} \mathrm{W}\right)$, Atmos. Environ., 36, 4479-4490, 2002.

Köble, R. and Seufert, G.: Novel Maps for Forest Tree Species in Europe,, in: A Changing Atmosphere, 8th European Symposium on the Physico-Chemical Behaviour of Atmospheric Pollutants, Torino, Italy, 17-20 September 2001., available at: http://ies.jrc.ec.europa.eu/Units/cc/events/torino2001/_ torinocd/Documents/Terrestrial/TP35.htm (last access: February 2012), 2001.

Kulmala, M., Asmi, A., Lappalainen, H. K., Baltensperger, U., Brenguier, J.-L., Facchini, M. C., Hansson, H.-C., Hov, Ø., O’Dowd, C. D., Pöschl, U., Wiedensohler, A., Boers, R., Boucher, O., de Leeuw, G., Denier van der Gon, H. A. C., Feichter, J., Krejci, R., Laj, P., Lihavainen, H., Lohmann, U., McFiggans, G., Mentel, T., Pilinis, C., Riipinen, I., Schulz, M., Stohl, A., Swietlicki, E., Vignati, E., Alves, C., Amann, M., Ammann, M., Arabas, S., Artaxo, P., Baars, H., Beddows, D. C. S., Bergström, R., Beukes, J. P., Bilde, M., Burkhart, J. F., Canonaco, F., Clegg, S. L., Coe, H., Crumeyrolle, S., D'Anna, B., Decesari, S., Gilardoni, S., Fischer, M., Fjaeraa, A. M., Fountoukis, C., George, C., Gomes, L., Halloran, P., Hamburger, T., Harrison, R. M., Herrmann, H., Hoffmann, T., Hoose, C., Hu, M., Hyvärinen, A., Hõrrak, U., Iinuma, Y., Iversen, T., Josipovic, M., Kanakidou, M., Kiendler-Scharr, A., Kirkevåg, A., Kiss, G., Klimont, Z., Kolmonen, P., Komppula, M., Kristjánsson, J.-E., Laakso, L., Laaksonen, A., Labonnote, L., Lanz, V. A., Lehtinen, K. E. J., Rizzo, L. V., Makkonen, R., Manninen, H. E., McMeeking, G., Merikanto, J., Minikin, A., Mirme, S., Morgan, W. T., Nemitz, E., O’Donnell, D., Panwar, T. S., Pawlowska, H., Petzold, A., Pienaar, J. J., Pio, C., Plass-Duelmer, C., Prévôt, A. S. H., Pryor, S., Reddington, C. L., Roberts, G., Rosenfeld, D., Schwarz, J., Seland, Ø., Sellegri, K., Shen, X. J., Shiraiwa, M., Siebert, H., Sierau, B., Simpson, D., Sun, J. Y., Topping, D., Tunved, P., Vaattovaara, P., Vakkari, V., Veefkind, J. P., Visschedijk, A., Vuollekoski, H., Vuolo, R., Wehner, B., Wildt, J., Woodward, S., Worsnop, D. R., van Zadelhoff, G.-J., Zardini, A. A., Zhang, K., van Zyl, P. G., Kerminen, V.-M., Carslaw, S., K., and Pandis, S. N.: General overview: European Integrated project on Aerosol Cloud Climate and Air Quality interactions (EUCAARI) - integrating aerosol research from nano to global scales, Atmos. Chem. Phys., 11, 13061-13143, doi:10.5194/acp11-13061-2011, 2011.

Kupiainen, K. and Klimont, Z.: Primary emissions of submicron and carbonaceous particles and the potential for their control., IIASA IR-04-079, International Institute for Applied Systems Analysis (IIASA), 2004.

Kupiainen, K. and Klimont, Z.: Primary emissions of fine carbonaceous particles in Europe, Atmos. Environ., 41, 2156-2170, doi:10.1016/j.atmosenv.2006.10.066, 2007. 
Laj, P., Klausen, J., Bilde, M., Plaß-Duelmer, C., Pappalardo, G., Clerbaux, C., Baltensperger, U., Hjorth, J., Simpson, D., Reimann, S., Coheur, P.-F., Richter, A., Mazière, M. D., Rudich, Y., McFiggans, G., Torseth, K., Wiedensohler, A., Morin, S., Schulz, M., Allan, J., Attié, J.-L., Barnes, I., Birmilli, W., Cammas, P., Dommen, J., Dorn, H.-P., Fowler, D., Fuzzi, J.-S., Glasius, M., Granier, C., Hermann, M., Isaksen, I., Kinne, S., Koren, I., Madonna, F., Maione, M., Massling, A., Moehler, O., Mona, L., Monks, P., Müller, D., Müller, T., Orphal, J., Peuch, V.-H., Stratmann, F., Tanré, D., Tyndall, G., Riziq, A., Roozendael, M. V., Villani, P., Wehner, B., Wex, H., and Zardini, A.: Measuring Atmospheric Composition Change, Atmos. Environ., 43, 5351-5414, doi:10.1016/j.atmosenv.2009.08.020, 2009.

Lane, T. E., Donahue, N. M., and Pandis, S. N.: Effect of $\mathrm{NO}_{\mathrm{x}}$ on secondary organic aerosol concentrations, Environ. Sci. Technol., 42, 6022-6027, doi:10.1021/es703225a, 2008a.

Lane, T. E., Donahue, N. M., and Pandis, S. N.: Simulating secondary organic aerosol formation using the volatility basis-set approach in a chemical transport model, Atmos. Environ., 42, 7439-7451, doi:10.1016/j.atmosenv.2008.06.026, 2008b.

Lanz, V. A., Prévôt, A. S. H., Alfarra, M. R., Weimer, S., Mohr, C., DeCarlo, P. F., Gianini, M. F. D., Hueglin, C., Schneider, J., Favez, O., D'Anna, B., George, C., and Baltensperger, U.: Characterization of aerosol chemical composition with aerosol mass spectrometry in Central Europe: an overview, Atmos. Chem. Phys., 10, 10453-10471, doi:10.5194/acp-10-10453-2010, 2010.

Legrand, M. and Puxbaum, H.: Summary of the CARBOSOL project: Present and retrospective state of organic versus inorganic aerosol over Europe, J. Geophys. Res., 112, D23S01, doi:10.1029/2006JD008271, 2007.

Li, G., Bei, N., Tie, X., and Molina, L. T.: Aerosol effects on the photochemistry in Mexico City during MCMA2006/MILAGRO campaign, Atmos. Chem. Phys., 11, 51695182, doi:10.5194/acp-11-5169-2011, 2011.

McDonald, J. D., Eide, I., Seagrave, J., Zielinska, B., Whitney, K., Lawson, D. R., and Mauderly, J. L.: Relationship between Composition and Toxicity of Motor Vehicle Emission Samples, Environ. Health Persp., 112, 1527-1538, 2004.

McKay, M. D., Beckman, R. J., and Conover, W. J.: A Comparison of Three Methods for Selecting Values of Input Variables in the Analysis of Output from a Computer Code, Technometrics, 21, 239-245, http://www.jstor.org/stable/1268522, 1979.

Mohr, C., DeCarlo, P. F., Heringa, M. F., Chirico, R., Slowik, J. G., Richter, R., Reche, C., Alastuey, A., Querol, X., Seco, R., Peñuelas, J., Jiménez, J. L., Crippa, M., Zimmermann, R., Baltensperger, U., and Prévôt, A. S. H.: Identification and quantification of organic aerosol from cooking and other sources in Barcelona using aerosol mass spectrometer data, Atmos. Chem. Phys., 12, 1649-1665, doi:10.5194/acp-12-1649-2012, 2012.

Murphy, B. N. and Pandis, S. N.: Simulating the Formation of Semivolatile Primary and Secondary Organic Aerosol in a Regional Chemical Transport Model, Environ. Sci. Technol., 43, 4722-4728, doi:10.1021/es803168a, 2009.

Ng, N. L., Kroll, J. H., Chan, A. W. H., Chhabra, P. S., Flagan, R. C., and Seinfeld, J. H.: Secondary organic aerosol formation from m-xylene, toluene, and benzene, Atmos. Chem. Phys., 7, 3909-3922, doi:10.5194/acp-7-3909-2007, 2007a.

Ng, N. L., Chhabra, P. S., Chan, A. W. H., Surratt, J. D., Kroll, J. H., Kwan, A. J., McCabe, D. C., Wennberg, P. O., Sorooshian,
A., Murphy, S. M., Dalleska, N. F., Flagan, R. C., and Seinfeld, J. H.: Effect of $\mathrm{NO}_{\mathrm{x}}$ level on secondary organic aerosol (SOA) formation from the photooxidation of terpenes, Atmos. Chem. Phys., 7, 5159-5174, doi:10.5194/acp-7-5159-2007, 2007b.

Ng, N. L., Canagaratna, M. R., Zhang, Q., Jimenez, J. L., Tian, J., Ulbrich, I. M., Kroll, J. H., Docherty, K. S., Chhabra, P. S., Bahreini, R., Murphy, S. M., Seinfeld, J. H., Hildebrandt, L., Donahue, N. M., DeCarlo, P. F., Lanz, V. A., Prévôt, A. S. H., Dinar, E., Rudich, Y., and Worsnop, D. R.: Organic aerosol components observed in Northern Hemispheric datasets from Aerosol Mass Spectrometry, Atmos. Chem. Phys., 10, 46254641, doi:10.5194/acp-10-4625-2010, 2010.

Novakov, T. and Penner, J.: Large contribution of organic aerosols to cloud condensation nuclei concentrations, Nature, 365, 823826, 1993.

Pathak, R. K., Presto, A. A., Lane, T. E., Stanier, C. O., Donahue, N. M., and Pandis, S. N.: Ozonolysis of $\alpha$-pinene: parameterization of secondary organic aerosol mass fraction, Atmos. Chem. Phys., 7, 3811-3821, doi:10.5194/acp-7-3811-2007, 2007.

Pio, C. A., Legrand, M., Oliveira, T., Afonso, J., Santos, C., Caseiro, A., Fialho, P., Barata, F., Puxbaum, H., Sanchez-Ochoa, A., Kasper-Giebl, A., Gelencser, A., Preunkert, S., and Schock, M.: Climatology of aerosol composition (organic versus inorganic) at nonurban sites on a west-east transect across Europe, J. Geophys. Res., 112, D23S02, doi:10.1029/2006JD008038, 2007.

Putaud, J.-P., Raes, F., Van Dingenen, R., Bruggemann, E., Facchini, M. C., Decesari, S., Fuzzi, S., Gehrig, R., Huglin, C., Laj, P., Lorbeer, G., Maenhaut, W., Mihalopoulos, N., Muller, K., Querol, X., Rodriguez, S., Schneider, J., Spindler, G., Brink, H. t., Torseth, K., and Wiedensohler, A.: A European aerosol phenomenology-2: chemical characteristics of particulate matter at kerbside, urban, rural and background sites in Europe, Atmos. Environ., 38, 2579-2595, 2004.

Robinson, A. L., Donahue, N. M., Shrivastava, M. K., Weitkamp, E. A., Sage, A. M., Grieshop, A. P., Lane, T. E., Pierce, J. R., and Pandis, S. N.: Rethinking Organic Aerosols: Semivolatile Emissions and Photochemical Aging, Science, 315, 1259-1262, doi:10.1126/science.1133061, 2007.

Seco, R., Peñuelas, J., Filella, I., Llusià, J., Molowny-Horas, R., Schallhart, S., Metzger, A., Müller, M., and Hansel, A.: Contrasting winter and summer VOC mixing ratios at a forest site in the Western Mediterranean Basin: the effect of local biogenic emissions, Atmos. Chem. Phys., 11, 13161-13179, doi:10.5194/acp11-13161-2011, 2011.

Schauer, J., Kleeman, M., Cass, G., and Simoneit, B.: Measurement of Emissions from Air Pollution Sources. 4. C1-C27 Organic Compounds from Cooking with Seed Oils, Environ. Sci. Technol., 36, 567-575, 2002.

Schauer, J. J., Rogge, W. F., Hildemann, L. M., Mazurek, M. A., Cass, G. R., and Simoneit, B. R. T.: Source apportionment of airborne particulate matter using organic compounds as tracers, Atmos. Environ., 30, 3837-3855, 1996.

Shrivastava, M., Fast, J., Easter, R., Gustafson Jr., W. I., Zaveri, R. A., Jimenez, J. L., Saide, P., and Hodzic, A.: Modeling organic aerosols in a megacity: comparison of simple and complex representations of the volatility basis set approach, Atmos. Chem. Phys., 11, 6639-6662, doi:10.5194/acp-11-6639-2011, 2011.

Shrivastava, M. K., Lane, T. E., Donahue, N. M., Pandis, S. N., and Robinson, A. L.: Effects of gas particle partitioning 
and aging of primary emissions on urban and regional organic aerosol concentrations, J. Geophys. Res., 113, D18301 doi:10.1029/2007JD009735, 2008.

Simon, H., Bhave, P. V., Swall, J. L., Frank, N. H., and Malm, W. C.: Determining the spatial and seasonal variability in $\mathrm{OM} / \mathrm{OC}$ ratios across the US using multiple regression, Atmos. Chem. Phys., 11, 2933-2949, doi:10.5194/acp-11-2933-2011, 2011.

Simpson, D., Winiwarter, W., Börjesson, G., Cinderby, S., Ferreiro, A., Guenther, A., Hewitt, C. N., Janson, R., Khalil, M. A. K., Owen, S., Pierce, T. E., Puxbaum, H., Shearer, M., Skiba, U., Steinbrecher, R., Tarrasón, L., and Öquist, M. G.: Inventorying emissions from Nature in Europe, J. Geophys. Res., 104, 81138152, 1999.

Simpson, D., Fagerli, H., Jonson, J., Tsyro, S., Wind, P., and Tuovinen, J.-P.: The EMEP Unified Eulerian Model. Model Description, EMEP MSC-W Report 1/2003, The Norwegian Meteorological Institute, Oslo, Norway, 2003.

Simpson, D., Butterbach-Bahl, K., Fagerli, H., Kesik, M., Skiba, U., and Tang, S.: Deposition and Emissions of Reactive Nitrogen over European Forests: A Modelling Study, Atmos. Environ., 40, 5712-5726, doi:10.1016/j.atmosenv.2006.04.063, 2006a.

Simpson, D., Fagerli, H., Hellsten, S., Knulst, J. C., and Westling, O.: Comparison of modelled and monitored deposition fluxes of sulphur and nitrogen to ICP-forest sites in Europe, Biogeosciences, 3, 337-355, doi:10.5194/bg-3-337-2006, 2006b.

Simpson, D., Yttri, K., Klimont, Z., Kupiainen, K., Caseiro, A., Gelencsér, A., Pio, C., and Legrand, M.: Modeling Carbonaceous Aerosol over Europe. Analysis of the CARBOSOL and EMEP EC/OC campaigns, J. Geophys. Res., 112, D23S14, doi:10.1029/2006JD008158, 2007.

Simpson, D., Yttri, K., Bergström, R., and Denier van der Gon, H.: Modelling SOA in EMEP: Experiments with the VBS Approach, in: Transboundary Particulate Matter in Europe, Status Report 4/2004, Tørseth, K. (ed.), EMEP CCC Report 4/2009, Norwegian Institute for Air Research, Kjeller, Norway, 2009.

Simpson, D., Benedictow, A., Berge, H., Bergström, R., Emberson, L. D., Fagerli, H., Flechard, C. R., Hayman, G. D., Gauss, M., Jonson, J. E., Jenkin, M. E., Nyíri, A., Richter, C., Semeena, V. S., Tsyro, S., Tuovinen, J.-P., Valdebenito, Á., and Wind, P.: The EMEP MSC-W chemical transport model - technical description, Atmos. Chem. Phys., 12, 7825-7865, doi:10.5194/acp-127825-2012, 2012.

Szidat, S., Ruff, M., Perron, N., Wacker, L., Synal, H.-A., Hallquist, M., Shannigrahi, A. S., Yttri, K. E., Dye, C., and Simpson, D.: Fossil and non-fossil sources of organic carbon (OC) and elemental carbon (EC) in Göteborg, Sweden, Atmos. Chem. Phys., 9, 1521-1535, doi:10.5194/acp-9-1521-2009, 2009.

Tarrasón, L., Fagerli, H., Gauss, M., Nyíri, A., Simpson, D., Tsyro, S., and Aas, W.: $\mathrm{S}, \mathrm{N}$ and $\mathrm{O}_{3}$ in EECCA countries, in: Transboundary Acidification, Eutrophication and Ground Level Ozone in Europe in 2006. EMEP Status Report 1/2008, pp. 67-86, The Norwegian Meteorological Institute, Oslo, Norway, 2008.

Tørseth, K., Aas, W., Breivik, K., Fjæraa, A. M., Fiebig, M., Hjellbrekke, A. G., Lund Myhre, C., Solberg, S., and Yttri, K. E.: Introduction to the European Monitoring and Evaluation Programme (EMEP) and observed atmospheric composition change during 1972-2009, Atmos. Chem. Phys., 12, 5447-5481, doi:10.5194/acp-12-5447-2012, 2012.
Tsimpidi, A. P., Karydis, V. A., Zavala, M., Lei, W., Molina, L., Ulbrich, I. M., Jimenez, J. L., and Pandis, S. N.: Evaluation of the volatility basis-set approach for the simulation of organic aerosol formation in the Mexico City metropolitan area, Atmos. Chem. Phys., 10, 525-546, doi:10.5194/acp-10-525-2010, 2010.

Tsyro, S., Simpson, D., Tarrasón, L., Kupiainen, K., Klimont, Z., Yttri, K., and Pio, C.: Modelling of black carbon over Europe, J. Geophys. Res., 112, D23S19, doi:10.1029/2006JD008164, 2007.

Turpin, B. J. and Lim, H. J.: Species contributions to $\mathrm{PM}_{2.5}$ mass concentrations: Revisiting common assumptions for estimating organic mass, Aerosol Sci. Technol., 35, 602-610, 2001.

UN-ECE: International Co-operative Programme on Assessment and Monitoring of Air Pollution Effects on Forests. Manual on methods and criteria for harmonized sampling, assessment, monitoring and analysis of the effects of air pollution on forests, updated version available at: (http://icp-forests.net) (last access: February 2012), 1998.

Vaden, T. D., Imre, D., Beránek, J., Shrivastava, M., and Zelenyuk, A.: Evaporation kinetics and phase of laboratory and ambient secondary organic aerosol, P. Natl. Acad. Sci. USA, 108, 2190 2195, 2011.

van der Werf, G. R., Randerson, J. T., Giglio, L., Collatz, G. J., Kasibhatla, P. S., and Arellano Jr., A. F.: Interannual variability in global biomass burning emissions from 1997 to 2004, Atmos. Chem. Phys., 6, 3423-3441, doi:10.5194/acp-6-3423-2006, 2006.

Visschedijk, A. J. H., Denier van der Gon, H. A. C., Dröge, R., and Van der Brugh, H.: A European high resolution and sizedifferentiated emission inventory for elemental and organic carbon for the year 2005, TNO TNO-034-UT-2009-00688_PT-ML, TNO, Utrecht, The Netherlands, 2009.

Watson, J., Chow, J., and Chen, L.-W.: Summary of organic and elemental carbon/black carbon analysis methods and intercomparisons, Aerosol Air Qual. Res., 5, 65-102, 2005.

Winiwarter, W., Bauer, H., Caseiro, A., and Puxbaum, H.: Quantifying emissions of primary biological aerosol particle mass in Europe, Atmos. Environ., 43, 1403-1409, doi:10.1016/j.atmosenv.2008.01.037, 2009.

Yttri, K. E., Aas, W., Bjerke, A., Cape, J. N., Cavalli, F., Ceburnis, D., Dye, C., Emblico, L., Facchini, M. C., Forster, C., Hanssen, J. E., Hansson, H. C., Jennings, S. G., Maenhaut, W., Putaud, J. P., and Tørseth, K.: Elemental and organic carbon in $\mathrm{PM}_{10}$ : a one year measurement campaign within the European Monitoring and Evaluation Programme EMEP, Atmos. Chem. Phys., 7, 5711-5725, doi:10.5194/acp-7-5711-2007, 2007.

Yttri, K., Aas, W., Tørseth, K., Stebel, K., Nyíri, A., Tsyro, S., Merckova, K., Wankmüller, R., Winiwarter, W., Bauer, H., Caseiro, A., Puxbaum, H., Holzer-Popp, T., and Schroedter-Homscheidt, M.: Transboundary particulate matter in Europe - Status report 2008, EMEP Status Report 4/2008, NILU, available at: http: //www.emep.int (last access: February 2012), 2008.

Yttri, K. E., Simpson, D., Stenström, K., Puxbaum, H., and Svendby, T.: Source apportionment of the carbonaceous aerosol in Norway - quantitative estimates based on ${ }^{14} \mathrm{C}$, thermal-optical and organic tracer analysis, Atmos. Chem. Phys., 11, 9375-9394, doi:10.5194/acp-11-9375-2011, 2011. 